\section{UCDNN}

LIBRARY
University of Connecticut OpenCommons@UConn

Faculty Articles and Papers

School of Law

6-14-2011

\title{
The First Liability Insurance Cartel in America, 1896-1906
}

Sachin S. Pandya

Univ. of Connecticut School of Law, sachin.pandya@uconn.edu

Follow this and additional works at: https://opencommons.uconn.edu/law_papers

Part of the Antitrust and Trade Regulation Commons, Insurance Law Commons, and the Legal History Commons

\section{Recommended Citation}

Pandya, Sachin S., "The First Liability Insurance Cartel in America, 1896-1906" (2011). Faculty Articles and Papers. 2. https://opencommons.uconn.edu/law_papers/2 


\title{
The First Liability Insurance Cartel in America, 1896-1906
}

\author{
SACHIN S. PANDYA
}

This article studies the rise and fall of the first liability insurance cartel in the United States. In 1886, insurance companies in America began selling liability insurance for personal injury accidents, primarily to cover business tort liability for employee accidents at work and non-employee injuries occasioned by their business operations. ${ }^{1}$ In 1896 , the leading liability insurers agreed to fix premium rates and share information on policyholder losses. In 1906, this cartel fell apart.

Although largely forgotten until now, the rise and fall of this cartel confirms the expectations of both cartel theory and past studies of insurance cartels, largely in fire insurance, showing how insurers engaged in unstable price-fixing efforts and shared information to better estimate future claims costs. $^{2}$ Moreover, this liability insurance cartel offers a

1. Capt. A.W. Masters, "Policy Forms in Liability Insurance," The Standard (Extra Number) (1894): xxvi; see also Employers' Liability Assurance Corp. v. Merrill, 29 N.E. 529, 529-30 (Mass. 1892) (generally describing the various types of liability insurance policies sold by the Employers' Liability Assurance Corporation).

2. See Dalit Baranoff, "A Policy Of Cooperation: The Cartelisation of American Fire Insurance, 1873-1906," Financial History Review 10 (2003): 119-36; Marc Schneiberg, "Political and Institutional Conditions for Governance by Association: Private Order and Price Controls in American Fire Insurance," Politics \& Society 27 (1999): 67-103; William Hamlin Wandel, The Control of Competition in Fire Insurance (Lancaster: The Art Print. Co., 1935); and Robert Riegel, "Rate-Making Organizations in Fire Insurance," Annals of the American Academy of Political and Social Science 70 (March 1917):

Sachin S. Pandya is associate professor of law at University of Connecticut School of Law, <sachin.pandya@law.uconn.edu>. For comments on earlier drafts of this article, the author thanks Peter Siegelman, four anonymous reviewers, and participants at the 2009 meeting of the American Society for Legal History. 
deviant case for standard accounts of how law and legal institutions influenced industrial organization in the United States at the turn of the twentieth century.

In standard accounts of industrial organization at this time, researchers largely emphasize how firms across industries moved from cartels to horizontal mergers as strategies to control price competition. The firms joining cartels were largely in relatively new capital-intensive mass-production industries that had been rapidly expanding on the eve of the Depression of 1893. Given their high fixed costs, those firms responded to the decline in demand by lowering prices, and then, to control the ensuing price competition, by forming cartels to fix prices or production levels. From 1895 to 1904, about twenty percent of industries experienced significant consolidation activity. ${ }^{3}$ Some scholars explain this merger wave by pointing to legal factors. By 1895, the Sherman Act clearly prohibited cartel agreements, but did not clearly preclude consolidation through state-chartered corporations, whereas states could have, but largely did not, use their powers under state corporate law to restrict horizontal mergers. ${ }^{4}$

172-98. For Great Britain and Australia, see Robin Pearson, Insuring the Industrial Revolution: Fire Insurance in Great Britain, 1700-1850 (Burlington: Ashgate Publishing Co., 2004), 149-56; and Monica Keneley, "The Origins of Formal Collusion in Australian Fire Insurance 1870-1920," Australian Economic History Review 42 (2002): 54-76. Early life insurers in the United States appear to have pooled information to better estimate mortality risk. Sharon Ann Murphy, Investing in Life: Insurance in Antebellum America (Baltimore: Johns Hopkins Press, 2010), 241-54.

3. Neil Fligstein, The Transformation of Corporate Control (Cambridge: Harvard University Press, 1990), 38-52, 317-19; Naomi R. Lamoreaux, The Great Merger Movement in American Business, 1895-1904 (Cambridge: Cambridge University Press, 1985).

4. Fligstein, Transformation, 59-74, 317-21; and George Bittlingmayer, "Did Antitrust Policy Cause the Great Merger Wave?," Journal of Law \& Economics 28 (1985): 77118. But see Martin J. Sklar, The Corporate Reconstruction of American Capitalism, 1890-1916 (Cambridge: Cambridge University Press, 1988), 159-63; and Donald J. Smythe, "The Supreme Court and the Trusts: Antitrust and the Foundations of Modern American Business Regulation from Knight to Swift," U.C. Davis Law Review 39 (2005): 85-147. On state failure in restricting horizontal mergers, see Herbert Hovenkampf, Enterprise and American Law, 1836-1937 (Cambridge: Harvard University Press, 1991), 241-67; and Charles W. McCurdy, "The Knight Sugar Decision of 1895 and The Modernization of American Corporation Law, 1869-1903," Business History Review 53 (1979): 336-40. On state statutory law governing mergers and inter-corporate stock holding, see William G. Roy, Socializing Capital: The Rise of the Large Industrial Corporation in America (Princeton: Princeton University Press, 1997), 144-75; and Jonathan Chausovksy, "State Regulation of Corporations in the Late Nineteenth Century: A Critique of the New Jersey Thesis," Studies in American Political Development 21 (2007): 57-64. 
For some, however, the standard accounts have largely ignored or suppressed substantial variation within and across industries along many dimensions of industrial organization, including cost structure, organizational form, and inter-firm cooperation. ${ }^{5}$ For example, Berk concludes that standard accounts of American industrialization have mistaken a part for the whole, based on past research on custom, specialty, and batch industries; the persistence of non-corporate organizational forms in fire insurance and electricity; and the fact that "only 22 percent of U.S. industry participated in the great merger wave."

Similarly, although the first liability insurance cartel does not challenge arguments about the influence of antitrust and corporate law on the merger wave, the story of its rise and fall raises the possibility that, in the eighty percent of industries that did not experience significant consolidation activity, possible legal influences on industrial organization may have substantially varied within and across industries in ways that standard accounts have not fully appreciated. ${ }^{7}$

First, the first liability insurance cartel does not easily fit standard accounts of the legal influences on industrial organization. Insurance companies generally enjoyed immunity from federal antitrust regulation. From 1869 until June 1944, the United States Supreme Court consistently declared that Congress' power under Article I of the United States Constitution to "regulate Commerce . . . among the several States" did not cover insurance, ${ }^{8}$ thereby arguably precluding action against insurance companies under the Sherman Act, which Congress had enacted pursuant to this power. ${ }^{9}$ This shield from federal antitrust regulation (partly revived

5. See Gerald Berk, Louis D. Brandeis and the Making of Regulated Competition, 19001932 (New York: Cambridge University Press, 2009), 7-14; Philip Scranton, Endless Novelty: Specialty Production and American Industrialization, 1865-1925 (Princeton: Princeton University Press, 1997); and Gerald Berk and Marc Schneiberg, "Varieties in Capitalism, Varieties of Association: Collaborative Learning in American Industry, 1900 to 1925," Politics \& Society 33 (2005): 46-87.

6. Berk, Louis D. Brandeis, 12.

7. An example is the influence of receivership law on the capital structure of American railroads. See, for example, Bradley Hansen, "The People's Welfare and the Origins of Corporate Reorganization: The Wabash Receivership Reconsidered," Business History Review 74 (2000): 377-405; and Peter Tufano, "Business Failure, Judicial Intervention, and Financial Innovation: Restructuring U.S. Railroads in the Nineteenth Century," Business History Review 71 (1997): 1-40.

8. Paul v. Virginia, 75 U.S. (8 Wall.) 168 (1869); United States v. South-Eastern Underwriters Association, 322 U.S. 533 (1944); Boris I. Bittker and Brannon P. Denning, Bittker on the Regulation of Interstate and Foreign Commerce (Gaithersburg: Aspen Law \& Business, 1999), § 3.08[A] at 3-48 (discussing Paul's progeny during this period).

9. Act of July 2, 1890, ch. 647, 26 Stat. 209. 
in 1945 by Congress $^{10}$ ) allocated regulatory authority over the insurance business in the States to state governments and state law, including state antitrust statutes, statutes that expressly barred some kinds of insurers from cooperative rate-setting, and state common law on unreasonable restraints of trade. Here, fire insurance and liability insurance diverge. Despite some lawsuits against fire insurance companies during this period, ${ }^{11}$ no one appears to have sued any member of the first liability insurance cartel for violating any such state law.

Second, the distinctive structure of the liability insurance market suggests a distinctive possible legal influence: state solvency regulation of liability loss reserves. Unlike traditional industries with high fixed costs, sellers of insurance only know what their policies actually cost sometime after sale, when their policyholders suffer losses during the term of the policy and seek payment. If the odds or severity of the insured event vary significantly over time, those future costs may be both hard to estimate accurately and vary with changes in industry norms for how to estimate those future costs. If an insurer underestimates future claims costs and sells at a lower price on that basis, the insurer may not set aside enough capital in reserve to cover claims when they later arise and must be paid. Moreover, if this insurer insolvency risk remains positive and hard for buyers to observe at the time of sale, new firms may try to lure buyers with lower prices by setting aside less in reserve, and therefore bearing higher insolvency risk. ${ }^{12}$

Faced with such price competition, insurers can conceivably adopt several strategies. They too can lower prices by setting aside less in reserve. They can, as part of product differentiation efforts, seek ways to credibly signal to buyers that they have lower insolvency risk than their rivals. They may share information with their rivals to more accurately estimate

10. Act of March 9, 1945, ch. 20, § 2(b), 59 Stat. 33, 34 (Sherman Act and other specified federal statutes "shall be applicable to the business of insurance to the extent such business is not regulated by state law").

11. "Legality of combinations or agreements between insurance companies or insurance agents," American Law Reports Annotated 21 (1922): 543-57 (collecting cases). For case studies, see H. Roger Grant, Insurance Reform: Consumer Action in the Progressive Era (Ames: Iowa State University Press, 1979), 71-89 (Missouri, Kansas, and Texas); and Steven J. Piott, The Anti-Monopoly Persuasion: Popular Resistance to the Rise of Big Business in the Midwest (Westport: Greenwood Press, 1985), 37-51, 136-37 (Missouri).

12. For a static Bertrand model that accounts for insurer capacity uncertainty but assumes that buyers can fully calculate insolvency risk, see Ray Rees, Hugh Gravelle, and Achim Wambach, "Regulation of Insurance Markets," Geneva Papers on Risk and Insurance 24 (1999): 65-66. For possible causes of change in liability risk between estimation and cost realization, see Tom Baker, "Insuring Liability Risk," Geneva Papers on Risk and Insurance 29 (2004): 128-49. 
their future claims costs, and with that, their own insolvency risk, if they compete for the same pool of buyers and they believe that their future claims costs will be highly correlated with those of their rivals. ${ }^{13}$ They may agree to fix prices as a way to jointly ameliorate price competition and secure monopoly profits. Or they may seek or support state regulation. For example, at the time State insurance codes typically required fire insurance companies to set aside fifty percent of gross annual premium income as an "unearned premium" reserve, ${ }^{14}$ that is, capital designated and set aside in advance to cover any and all future claims on policies that may occur before those policies expire.

The rise and fall of the first liability insurance cartel raises the possibility that under certain conditions, insurance firms may be motivated to join price-fixing arrangements in part to credibly signal to buyers that because they are cartel members, they have lower insolvency risk than their non-cartel rivals. ${ }^{15}$ If so, this suggests solvency regulation as a possible cause of the cartel's fall. By the 1890s, many states had statutes on the books to reduce insurance insolvency risk, both generally and for certain insurance lines, such as fire insurance. In this respect, however, state regulation of liability insurance differed from state regulation of fire insurance, because specific regulation of liability insurer loss reserves did not exist until 1901, and was limited until 1905. When such regulation began, it may have reduced the value of the cartel as a solvency signal, which thereby partly explains why the first liability insurance cartel fell apart shortly thereafter.

This article proceeds as follows. Part I describes the sources of cost uncertainty faced by the first liability insurers in the United States. Part II shows how, in 1896, the leading liability insurance companies formed the Conference of Liability Companies, and details the terms of their

13. For theory consistent with this expectation, see Michael Raith, "A General Model of Information Sharing in Oligopoly," Journal of Economic Theory 71 (1996): 267-68; Xavier Vives, "Trade Association Disclosure Rules, Incentives to Share Information, and Welfare," Rand Journal of Economics 21 (1990): 411-13; and Esther Gal-Or, "Information Transmission: Cournot and Bertrand Equilibria," Review of Economic Studies 53 (1986): 91-92.

14. Spencer Kimball, Insurance and Public Policy: A Study in the Legal Implementation of Social and Economic Public Policy, Based on Wisconsin Records, 1835-1959 (Madison: University of Wisconsin Press, 1960), 150-51 (early development of unearned premium reserve requirement in Wisconsin for fire and marine insurance companies); and F.C. Oviatt, "Historical Study of Fire Insurance in the United States," Annals of the American Academy of Political and Social Science 26 (1905): 164 (early unearned premium reserve requirements on fire insurers in Massachusetts and New York).

15. On forming producer associations to signal product quality in commodity markets, see Stéphan Marette and John M. Crespi, "Can Quality Certification Lead to Stable Cartels?," Review of Industrial Organization 23 (2003): 43-64. 
arrangement. Part III evaluates four possible complementary explanations for why this cartel abandoned its price-fixing effort in 1906: price competition from non-Conference rivals; defections by Conference members; state competition law; and state solvency regulation of liability insurance loss reserves. Of these, the article concludes that, given the available evidence, price competition from non-Conference rivals and state solvency regulation are plausible explanations, whereas state competition law is a less plausible one and the influence of Conference-member defections is unclear. The Conclusion identifies the limits of this article and suggests directions for future research.

\section{Background: Pricing Liability Risk}

This Part describes the uncertainties faced by the first liability insurers of personal injury accidents as they tried to set prices. It shows how they priced employers' liability insurance-a major type of liability insurance sold at the time - and how their uncertainty about future losses motivated both price competition and, for some insurers, efforts to signal buyers that they had less insolvency risk than their rivals.

The first liability insurer for personal injury accidents in the United States emerged in 1886, when George Endicott, a prominent fire and marine insurance broker in Boston, started the United States branch of the London-based Employers' Liability Assurance Corporation in a single room up one flight of stairs on State Street in Boston. ${ }^{16}$ Other companies quickly joined the liability insurance business - on one account, fourteen companies had joined by early $1894 .{ }^{17}$ Most of these early liability insurers were stock companies that sold multiple lines of insurance nationwide. For example, the Fidelity and Casualty Company, reportedly the first casualty company to sell multiple insurance lines, ${ }^{18}$ was by 1895 selling liability insurance as well as accident, burglary, fidelity, plate glass, and steam boiler insurance. ${ }^{19}$

16. "Death of the Pioneer of Employers' Liability Insurance in the United States," Weekly Underwriter, December 10, 1898, 331; and Harry Perry Robinson, The Employers' Liability Assurance Corporation Ltd., 1880-1930 (London: Waterlow \& Sons Ltd., 1930), 61-63.

17. E. W. De Leon, "Liability Insurance - Its Origin and Growth," The Spectator, April 26, 1894, 253.

18. Raymond N. Calverly, "The Background of the Casualty and Bonding Business in the United States," Insurance Counsel Journal 6 (October 1939): 63.

19. Thirty-Seventh Annual Report of the Superintendent of Insurance of the State of New York: Parts II, III, and IV. Life, Casualty, Title, Credit, Mortgage Guarantee and Assessment Insurance (Albany: James B. Lyon, 1896), 244. 
In pricing liability insurance, the first liability insurers faced the new and difficult task of accurately estimating policyholder liability risk. For a policy covering employer tort liability for workplace accidents, for example, insurers calculated the premium by multiplying an employer-provided estimate of the employer's payroll during the policy period with a premium rate, usually calculated in terms of $\$ 100$ of payroll. With the payroll estimate, the insurer could calculate the liability insurance policyholder's accident risk by type of trade or industry, ${ }^{20}$ much the way the Fidelity and Casualty Company did from 1889 to 1903 (Table 1).

The harder question was how to set the premium rate: the way to convert estimates of accident risk into estimates of liability risk. Initially, the first liability insurers based premium rates roughly on accident insurance premium rates, and then adjusted them on an ad hoc basis. ${ }^{21}$ Indeed, some companies may have deliberately published inflated premium rates in their rate manuals to make it easier for insurance agents to "cut" those rates to increase sales. ${ }^{22}$

Still, although these insurers also set aside an unearned premium reserve, ${ }^{23}$ uncertainty arose from the fact that most liability losses tended to accrue several years after the policy had expired. The accident and its liability loss did not happen at the same time. Rather, for every covered accident, the liability insurer only knew its actual cost after settlement, final judgment, or when the statute of limitations expired. In hindsight,

20. See W.F. Moore, "Liability Insurance," Annals of the American Academy of Political and Social Science 26 (1905): 325-26; A.W. Masters, paper on Liability Insurance, excerpted in Weekly Underwriter, September 9, 1899, 178; and Walter G. Cowles, "The Relation of Payroll to Certain Liability Lines," Weekly Underwriter, February 18, 1905, 143.

21. Stanley L. Otis, "The Bureau of Liability Insurance Statistics," The Spectator, November 12, 1908, 260.

22. Harris Brockway Johnson recalled that he created the first liability insurance manual for Travelers Insurance Company at the behest of Travelers President James G. Batterson: '[Batterson] immediately said, 'Harry, we must have a manual.' 'Why?' I asked.' 'The only reason the other companies have them is to show them and then cut the rates, making the prospect believe he's getting a bargain.' 'All right,' he said, 'we shall do the same.' So I made up the first Liability manual of The Travelers, and believe me I made the figures high enough to allow for substantial cuts." Harris Brockway Johnson, "Memories of a Remarkable Man," The Travelers Beacon 21 (Jan.-Feb. 1940): 3.

23. Sylvester C. Dunham, "Liability Insurance," in Yale Insurance Lectures, vol. 2 (Tuttle, Morehouse \& Taylor Press, 1904), 244-45; W. F. Moore, "Employers' Liability Insurance," in Insurance: "A Text-Book": A Compilation of the Addresses Delivered Before the Twenty-Ninth Session of the National Convention of Insurance Commissioners, Held at Milwaukee, Wisconsin, September 13-16, 1898, ed. William A. Fricke (Milwaukee: Published for the National Convention of Insurance Commissioners, 1898), 955; and Ralph H. Blanchard, Liability and Compensation Insurance (New York: D. Appleton \& Co., 1917), 265-67. 
Table 1. Fidelity and Casualty Company Liability Experience, 1889-1903, by Industry Type.

\begin{tabular}{|c|c|c|c|c|c|}
\hline Industry & $\begin{array}{c}\text { Wage } \\
\text { Expenditures }\end{array}$ & Accidents & $\begin{array}{l}\text { Persons Employed on Assumption of } \\
\$ 500 \text { Average Annual Wages }\end{array}$ & $\begin{array}{l}\text { Proportion of Persons } \\
\text { Injured: } 1 \text { in }\end{array}$ & $\begin{array}{c}\text { Accidents per } \\
\$ 100,000 \text { of Wages }\end{array}$ \\
\hline $\begin{array}{l}\text { Bakers and } \\
\text { Confectioners }\end{array}$ & $35,620,283$ & 1,729 & 71,241 & 41.20 & 4.85 \\
\hline Bridge Builders & $6,554,298$ & 2,855 & 13,109 & 4.59 & 43.56 \\
\hline $\begin{array}{l}\text { Carriage \& Wagon } \\
\text { Builders }\end{array}$ & $17,558,322$ & 1,180 & 35,117 & 29.76 & 6.72 \\
\hline $\begin{array}{l}\text { Chemical \& Color } \\
\text { Workers }\end{array}$ & $69,557,839$ & 5,587 & 139,116 & 24.90 & 8.03 \\
\hline Contractors & $151,473,698$ & 27,657 & 302,947 & 10.95 & 18.26 \\
\hline $\begin{array}{l}\text { Electric Light and } \\
\text { Power }\end{array}$ & $26,631,740$ & 3,749 & 53,263 & 14.21 & 14.08 \\
\hline Leather & $64,117,232$ & 2,420 & 128,234 & 52.99 & 3.77 \\
\hline Lumber & $129,698,868$ & 15,575 & 259,398 & 16.65 & 12.01 \\
\hline Metal Works & $377,064,010$ & 44,723 & 754,128 & 16.86 & 11.86 \\
\hline Milling & $14,471,238$ & 675 & 28,942 & 42.88 & 4.66 \\
\hline Mining & $115,264,632$ & 11,225 & 230,529 & 20.54 & 9.74 \\
\hline Miscellaneous & $190,763,263$ & 14,755 & 381,527 & 25.86 & 7.73 \\
\hline Oil & $12,081,597$ & 1,516 & 24,163 & 15.94 & 12.55 \\
\hline Ore Reduction & $28,025,226$ & 2,574 & 56,050 & 21.78 & 9.18 \\
\hline Paper & $55,382,868$ & 4,505 & 110,766 & 24.59 & 8.13 \\
\hline Pottery & $53,681,734$ & 2,422 & 107,363 & 44.33 & 4.51 \\
\hline
\end{tabular}




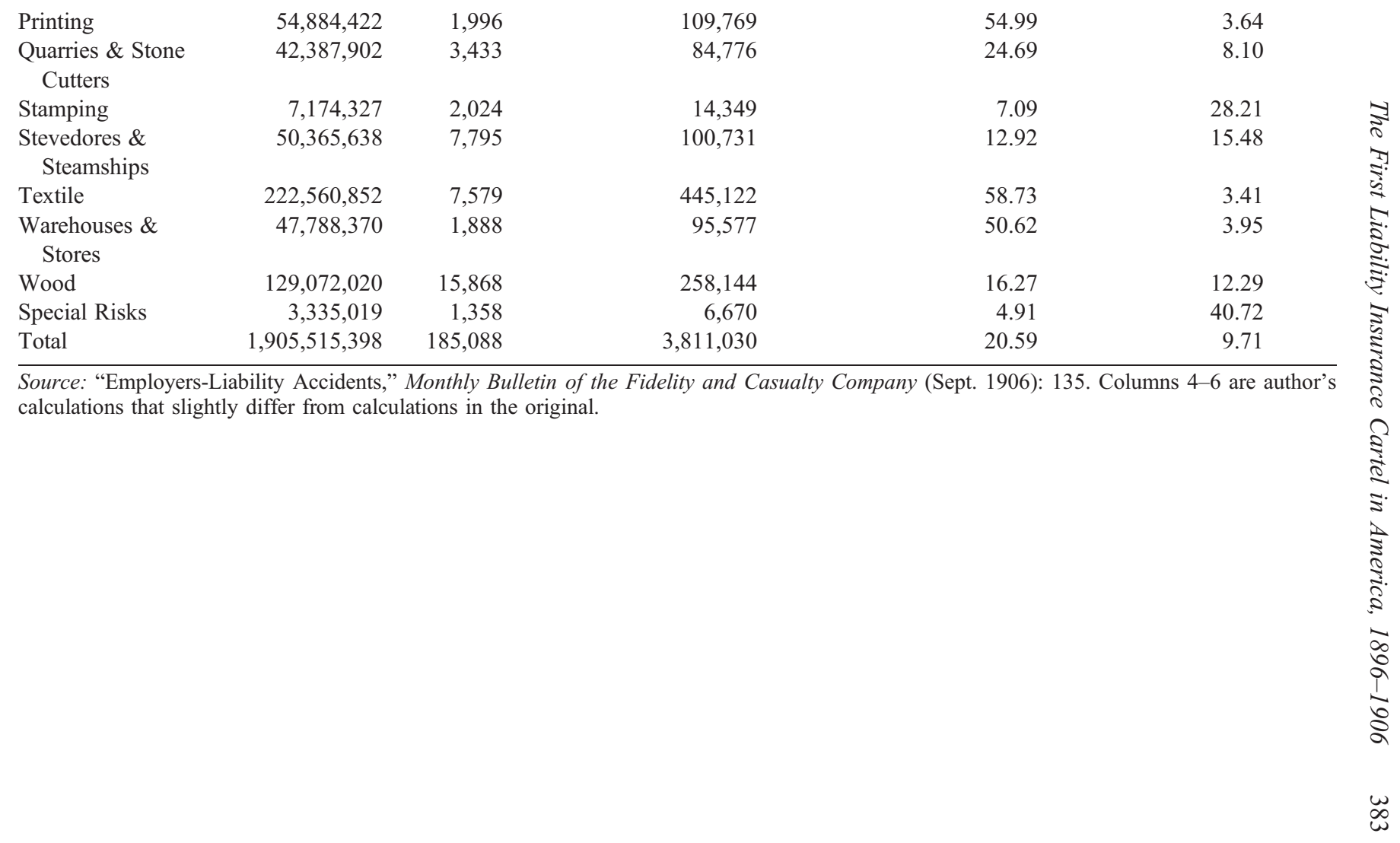



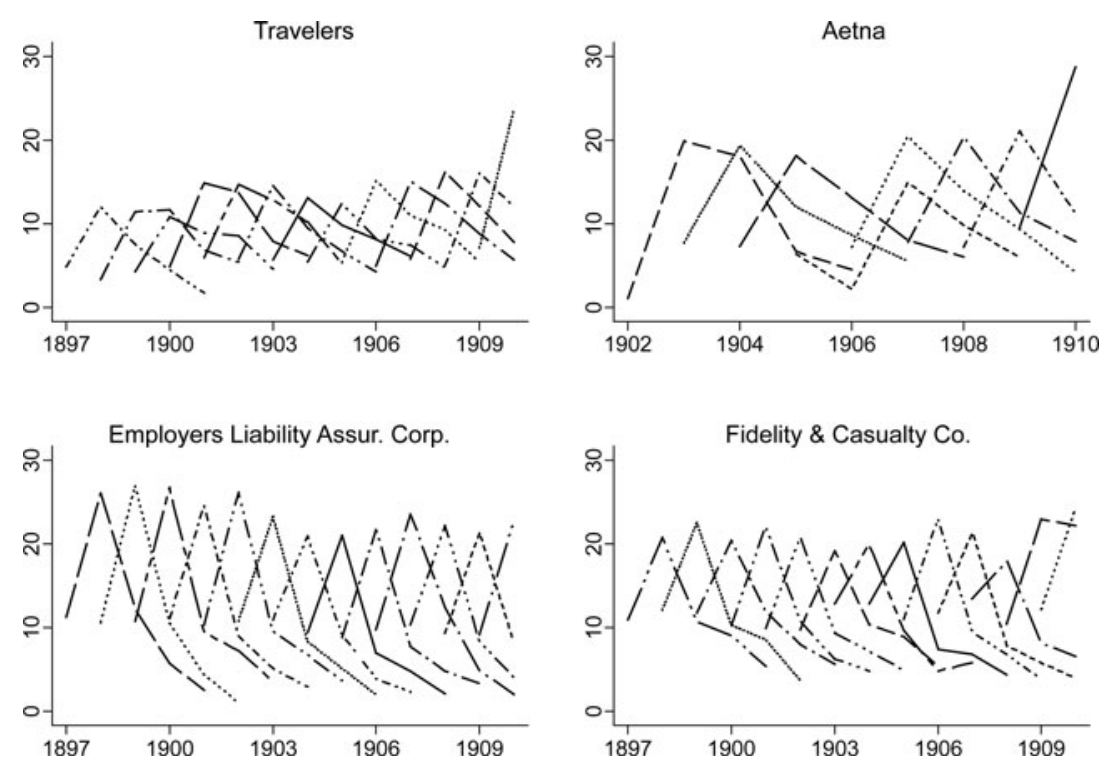

Figure 1. Five-year distribution of liability losses paid as a fraction of liability premiums collected in the policy year. Source: Report of Employers' Liability Commission to the Governor of Iowa (Des Moines: Emory H. English, 1912), 109-13 (based on data filed with Michigan Insurance Department). The Fidelity and Casualty Company asserted that, unlike some other companies, it did not include claims expenses with paid losses. "Michigan Loss Ratios," Monthly Bulletin of the Fidelity and Casualty Company (June 1905): 88.

we can see the actual distribution of liability losses across the years after the policy year. Figure 1 reports the average five-year distribution of losses for liability insurance policies nationwide for four major liability insurance companies doing business in Michigan. It shows that, for these companies, most of the loss costs associated with a particular year's liability insurance business occurred in the year immediately after the policy year, and dropped significantly thereafter. Others looked back at the distribution of losses paid under liability insurance policies over a ten-year period, and found similar results. ${ }^{24}$

24. Report of the Employers' Liability Commission of the State of Illinois (Chicago: Stromberg, Allen \& Co., 1910), 13-14; and William Penman, Jr., "On the Valuation of the Liabilities of an Insurance Company under its Employers' Liability Contracts," Journal of the Institute of Actuaries 45 (1911): 137-38 (comment by W.R. Strong). 
Without the benefit of hindsight, some liability insurers set aside each year, in addition to their unearned premium reserve, a special reserve specifically to cover future liability losses. This signal of solvency had credibility problems, because it was difficult for insurance buyers to know whether that reserve was adequate. Rather than rely on companies' own published figures, the Spectator, an insurance trade publication, counseled its readers in 1895 to look closely at the insurer's reputation, and in particular, to whether the insurer is defending "an unusually large percentage of suits rather than settling them," or is "appealing from an unusual percentage of verdicts." If so, that would indicate an increase in the average cost of its suits and claims, and render "fictious" the insurer's allotted reserve for unsettled claims and suits. ${ }^{25}$

Uncertain insolvency risk also resulted in price competition with rivals who took advantage of uncertain insolvency risk by setting aside less in reserve in order to sell their policies at lower prices. The older insurers often stressed that this practice-at the time called rate-cutting-increased insolvency risk. As Fidelity and Casualty's George Seward wrote to his agents in 1892, "It seems to be impossible for the newer companies to recognize the fact that there is a distant and contingent liability hanging over them. Because they don't meet their losses at once as in Fire Insurance, they seem to think that they will not occur. THE CONSEQUENCE IS THAT THEY SHOW A READINESS TO $\overline{\text { CUT }}$ RATES, WHICH IF PERSISTED, WILL LEAD THEM INTO BANKRUPTCY."26

By stressing rivals' rate-cutting, these insurers were engaged in a form of product differentiation by stressing their rivals' high insolvency risk and their lower insolvency risk. Thus, Seward reminded his insurance agents in 1901 to stress that the Fidelity and Casualty Company "is old in the business, well tried and of undoubted strength. In this way he will set forth the intrinsic value of the insurance offered by him, as against the lack of evidence of intrinsic value which can be offered by the rate-cutting agent." ${ }^{27}$ Yet, as the editors of the Spectator had put it in 1895, as the published statements of liability insurers "involve so much of the unknown," the "average manufacturer or merchant may be well pardoned for mistaking the apparent for the real, and considering that he has done well in

25. "The Condition of the Liability Insurance Companies," The Spectator, October 31, 1895: 204.

26. Letter to Field Agents, Liability Lines, Fidelity and Casualty Company, dated February 1, 1892 (capitalization and underline in original), in Box 2, Folder 1, Seward Papers, New York Historical Society, New York, NY.

27. "Cut Rate Competition," Monthly Bulletin of the Fidelity \& Casualty Company of New York 6 (April 1901): 56. 
accepting the policy of the company which offers the lowest premium rather than that which offers the greatest protection." 28

\section{The Rise of the Liability Conference}

In 1896, the major liability insurers agreed to fix prices and pool information on liability losses. This Part describes how they reached this agreement, its key terms, and how long it lasted.

On February 15, 1894, representatives of six leading liability insurers met at the Fifth Avenue Hotel in New York City. Their goal: to set premium rates, that is, to fix prices. ${ }^{29}$ By March, the group had agreed to adopt a uniform policy and set premium rates according to a "regular tariff." The agreement later fell apart, because of a last-minute defection by A. W. Masters, of the London Guarantee and Accident Company. ${ }^{30}$

In this first of several efforts to fix prices and pool liability loss data, the liability insurers were imitating the fire insurance business, which by the 1890s had allocated rate-setting authority to organizations of local fire insurance agents. ${ }^{31}$ (American liability insurers may also have been aware of contemporaneous rate-setting efforts by accident insurance companies in England. ${ }^{32}$ ) Among American liability insurers, Travelers Insurance Company President James G. Batterson, for one, urged rival liability insurance company managers also to adopt rate setting to solve the rate-cutting problem. ${ }^{33}$ After a second attempt fell apart in $1895,{ }^{34}$

28. "The Condition of the Liability Insurance Companies," The Spectator, October 31, $1895,204$.

29. Meeting of Casualty Companies, The Standard, February 17, 1894, 169; and Weekly Underwriter, February 17, 1894, 109.

30. "Employers' Liability Tariff Movement Blocked," The Standard, March 24, 1894, 315.

31. Baranoff, "A Policy of Cooperation," 119-36.

32. William R. Strong, "The Growth of Accident and Employers' Liability Insurance in Great Britain," in Proceedings of the Fourth International Congress on Actuaries: Held in New York, under the auspices of the Actuarial Society of America, August 31 to September 5, 1903 (New York: Actuarial Society of America, 1904): 685; Weekly Underwriter, May 30, 1896, 363; H.A.L. Cockerell and Edwin Green, The British Insurance Business: A Guide to its History \& Records, 2nd ed. (Sheffield: Sheffield Academic Press, 1994), 88.

33. See, for example, Batterson to Geo. M. Endicott, October 2, 1894, Vol. 2, President's Letters, p. 593; Scrapbooks, Letterbooks, \& Miscellaneous, Box 4; President's Interests; Executive, Record Group 2; Travelers Insurance Company, Hartford, CT. Hereafter, PL2 refers to items from this bound volume of letters.

34. Weekly Underwriter, June 29, 1895, 455; "Liability Companies' Agreement Receives a Set Back," The Standard, July 20, 1895, 57; Weekly Underwriter, August 17, 1895, 79; Batterson to Geo. M. Endicott, Esq. Chairman, etc., dated August 16, 1895, PL2, p. 724; 
Batterson continued to do so. ${ }^{35}$ Other justifications included the benefits of information pooling. As Fidelity and Casualty's George Seward recounted to an insurance journal publisher a few days after the second attempt began in 1895, the proposed information-pooling effort "was the most important .... The field is so new that some of the gentlemen who attended the conference can hardly be considered to ha[v]e knowledge enough of the loss ratio in different classifications to judge what premium they ought to secure." 36 If the prospect of monopoly profits also motivated company managers, they did not mention this motive publicly.

In 1896, on the third attempt, they succeeded. By March, the major liability insurance companies had formed what later became known as the Conference of Liability Companies. ${ }^{37}$ George Endicott was its first President. ${ }^{38}$ The companies agreed to set premium rates, adopt standard policy forms, appoint an arbitrator to disputes among them, and establish "a bureau of statistics" authorized to "to call for tabulations of the experience of each company to collate same, and to prepare for consideration such proposals as to change rate as the circumstances may call for." 39

In June 1896, the Conference's rules, regulations, and premium rate schedule went into effect. ${ }^{40}$ By September, the Conference had adopted a standard form liability insurance policy for each of the various types of liability lines. ${ }^{41}$ The Conference issued revised rate manuals several times thereafter, including October 1897, ${ }^{42}$ October 1898, May 1901, and December 1904. ${ }^{43}$ In its first manual, the Conference initially set liability premium rates based on the rates currently set by the Employers' Liability Assurance Corporation and the Fidelity and Casualty Company.

"Liability Insurance," The Spectator, July 2, 1896, 2; Weekly Underwriter, August 24, 1895, 87; and Weekly Underwriter, September 21, 1895, 134.

35. Batterson to Geo. F. Seward, Esq. Prest., Fidelity \& Casualty Co. N.Y., January 3, 1896, PL2, p. 816; and Batterson to Seward, January 9, 1896, PL2, p. 819-20.

36. Notes of George F. Seward at 1, enclosed with G. Seward to R.R. Dearden, April 3, 1895, Box 2, Folder 9, Seward Papers, New York Historical Society.

37. "Harmonious Meeting of Liability Companies," The Standard, February 29, 1896, 235; The Spectator, March 12, 1896, 145; and Weekly Underwriter, March 7, 1896, 156.

38. Robinson, Employers' Liability, 66; and Edson S. Lott, Pioneers of American Liability Insurance (New York: Montross \& Clarke Co., Inc., 1938), 104.

39. Quoted in "Favorable View of Liability Agreement," The Standard, March 7, 1896, 250.

40. Conference Liability Manual (1896), reprinted in The Insurance Year Book 1896-97: Life and Miscellaneous (New York: Spectator Co., 1896), 389.

41. The Spectator, September 3, 1896, 101.

42. Weekly Underwriter, October 23, 1897, 231; and "New Liability Rates Promulgated," The Standard, October 23, 1897, 416.

43. Otis, "The Bureau," 261. 
The ultimate goal was to set premium rates based on an analysis, by the Conference's Bureau of Statistics and Arbitration, of the loss-experience data collected from all of the participating companies. ${ }^{44}$ Stewart Marks, formerly of the Standard Life and Accident Insurance Company, had accepted the position as head of that Bureau: the Conference's chief actuary and its sole arbitrator, the final decider of disputes among members. ${ }^{45}$

The participating companies also agreed to fix prices by not selling liability insurance policies at premium rates below those set by the Conference in the Conference's Liability Manual. Whereas commissions to agents and special agents were left to company discretion, no Conference member could authorize commissions to brokers exceeding fifteen percent generally, or exceeding ten percent for commissions on premium dollars in excess of $\$ 1,000$. Moreover, no agent, special agent, or employee of a Conference company could "place any risk in any of the liability lines with any company not a party to the Conference agreement." And rebates of commissions, or any other effort to "cut" a rate below the Manual rate, were prohibited. ${ }^{46}$

The terms of the Conference Agreement would be enforced by its Bureau of Arbitration, in which the Agreement vested authority to

direct cancellation of any policy written in violation of this agreement; may order the company offending not to write the risk again for a period of one year; may direct the companies not to accept business from any broker who more than once violates the terms of this agreement, and may fine any company which permits any agent or employee to violate this agreement not more than $\$ 100$ for each violation thereof. Such fines shall be used to defray the miscellaneous expenses of the bureau. ${ }^{47}$

44. "Agreement Reached: Liability Underwriters Agree Upon Rates, Policy Forms, Etc.," Insurance Press, March 4, 1896, 1.

45. "Liability Insurance Items," The Spectator, April 30, 1896, 245; Weekly Underwriter, March 14, 1896, 174.

46. Conference Liability Manual (1896), reprinted in The Insurance Year Book 1896-97: Life and Miscellaneous (New York: Spectator Co., 1896): 390. These terms did not change substantially over the life of the Liability Conference, except that an agent of a Conference company could place a risk with a non-Conference company if the home office of that company gave written consent. See Manual of Liability Insurance: Rules and Rates, October, 1898 (n.d.), in The Insurance Year Book 1902-03: Life and Miscellaneous (New York: Spectator Co., 1902), 331; and Edwin W. De Leon, compiler, Manual of Liability Insurance Containing the Rules, Instructions, Rates and Classifications adopted by the Conference of Liability Companies and amended to January 1, 1905 (New York: Spectator Co., 1909), 31.

47. "The Liability Situation," The Spectator, October 17, 1898, 185 (quoting letter from Stewart Marks). 
The Conference arbitrator would receive word of disputes from the companies, which would filter disputes brought to them by agents, and the arbitrator would be the final authority in deciding those disputes. ${ }^{48}$

In contrast to rate-setting in fire insurance, in the structure of the Liability Conference, local associations of liability insurance agents took a subordinate role. By early May 1896, and at the urging of the Conference companies, insurance agents had set up local liability insurance associations in six cities-New York, Boston, Philadelphia, Baltimore, Chicago, and St. Louis. ${ }^{49}$ The Baltimore association, for example, required its members to sign a pledge not to rebate or reduce premiums in violation of the Conference Agreement. Although the local associations provided input on liability premium rates, ${ }^{50}$ unlike local fire insurance boards, the Conference itself retained the final authority to set rates.

The Conference lasted for about a decade, with members exiting the Conference during that time (Table 2).

By December 1904, Fidelity and Casualty, one of the four remaining Conference companies, waxed fatalistic about the "demoralized" liability line ${ }^{51}$ telling its agents: "[I]t is no part of our purpose to participate in any effort to make a new conference that shall include the rate-cutters.... When the existing Conference goes to pieces, as it may, we are out of liability conferences for good and all." 52 That month, the remaining Conference members agreed to maintain their rate agreement. ${ }^{53}$ In 1905 , the Liability Conference published its fourth manual, ${ }^{54}$ and the remaining members of the Conference decided to continue. ${ }^{55}$ Soon after, however, in

48. "Liability Conference Materially Strengthened," The Standard, September 12, 1896, 231.

49. "Will Support General Liability Agreement," The Standard, May 2, 1896, 464; see also Weekly Underwriter, May 2, 1896, 291-92 (Boston, New York); Weekly Underwriter, May 9, 1896, 307 (Philadelphia); and "New Liability Association for New Jersey," The Standard, February 6, 1897, 164.

50. "Reduced Liability Rates to be Promulgated," The Standard, May 23, 1896, 542 (New York Liability Association); The Standard, May 30, 1896, 574 (same); and "The New Liability Rates," The Standard, June 13, 1896, 612.

51. "Liability Conference," Monthly Bulletin of Fidelity \& Casualty Co. 9 (December 1904): 181.

52. "Liability Rates," Monthly Bulletin of Fidelity \& Casualty Co. 9 (December 1904): 181.

53. Weekly Underwriter, December 10, 1904, 411.

54. Edwin W. De Leon, compiler, Manual of Liability Insurance Containing the Rules, Instructions, Rates and Classifications adopted by the Conference of Liability Companies and amended to January 1, 1905 (New York: Spectator Co., 1909).

55. "Miscellaneous Items," The Spectator, September 21, 1905, 167; Weekly Underwriter, September 16, 1905, 188; "Decide to Continue the Liability Conference," The Standard, September 16, 1905, 259; and "Liability Conference," Insurance Press, September 20, 1905, 14. 
Table 2. Liability Conference Membership, 1896-1906.

\begin{tabular}{lll}
\hline Company & \multicolumn{1}{c}{ Start } & \multicolumn{1}{c}{ Exit } \\
\hline Employers' Liability Assurance Corporation & Feb. 1896 & Oct. 1904 \\
Travelers Insurance Company & Feb. 1896 & Oct. 1900 \\
Fidelity and Casualty Company & Feb. 1896 & March 1906 \\
United States Casualty Company & Feb. 1896 & March 1906 \\
Standard Life and Accident Insurance Company & Feb. 1896 & Nov. 1902 \\
London Guarantee and Accident Company & Feb. 1896 & March 1906 \\
Union Casualty and Surety Company & Feb. 1896 & Sept. 1899 \\
Maryland Casualty Company & Nov. 1899 & March 1906 \\
\hline
\end{tabular}

Sources: "Action By Liability Conference," The Spectator, March 29, 1906,181; Weekly Underwriter, March 24, 1906, 217; "Liability Conference Takes Important Action," The Standard, March 24, 1906, 289; "Employers' Withdraws From Liability Compact," The Standard, October 28, 1904, 409; "Pleased to Have Maryland as an Ally," The Standard, November 25, 1899, 500; "Maryland May Join Liability 'Compact'," The Standard, September 30, 1899, 316; "Liability Company Loses Detroit Company," The Standard, November 21, 1902, 482; "Travelers Quits Liability Compact After All," The Standard, October 6, 1900, 336; and "Harmonious Meeting of Liability Companies," The Standard, February 29, 1896, 235.

a Union Casualty and Surety transferred its liability business to the Maryland Casualty Company.

March 1906, the Conference members voted to abandon the rule prohibiting competition among members. ${ }^{56}$ Although two new companies would join the Conference later that summer, ${ }^{57}$ the Conference was now purely an information-pooling arrangement. By January 1908, the Spectator reported that the Conference manual of liability premium rates "has become a dead letter, discredited and abandoned. All the companies are going alone, like a vessel where the master has discarded the compass." ${ }^{58}$

\section{Explanations for the Fall}

This Part evaluates four of the possible reasons why the Conference's cartel arrangement collapsed in 1906: (1) price competition from non-Conference rivals; (2) cheating by Conference members; (3) state competition law; and (4) state solvency regulation of liability loss reserves. The available evidence suggests that price competition by non-cartel rivals played an important role; the influence of defection by fellow cartel

56. "Action By Liability Conference," The Spectator, March 29, 1906, 181; Weekly Underwriter, March 24, 1906, 217; Weekly Underwriter, April 14, 1906, 275; "Liability Conference Takes Important Action," The Standard, March 24, 1906, 289; and "President Stone on the Liability Conference," The Standard, April 14, 1906, 356.

57. "Liability Conference Gains Two New Members," The Standard, August 4, 1906, 98. 58. "Liability Underwriters," The Spectator, January 9, 1908, 21. 
members is unclear; and state competition law appears not to have made much of a difference. The available evidence also is consistent with a fourth plausible cause: State solvency regulation of liability insurance loss reserves might have reduced the value of cartel membership as a signal of company solvency.

\section{A. Price Competition from Non-Conference Firms}

Price competition from rival non-Conference firms played an important role in the demise of the Liability Conference's price-fixing effort. As more firms entered the liability insurance market, the share of that market held by the Conference members began to fall and market concentration sharply declined (Figure 2). If market concentration implies market power to set prices, ${ }^{59}$ this decline suggests that the Liability Conference's price-fixing effort became less successful over time.

In accord with this conclusion, reports in the insurance trade press suggest that at least two Conference members left the Conference because of price competition from non-Conference firms. In November 1902, the Standard Life and Accident Company of Detroit withdrew from the Liability Conference. ${ }^{60}$ Its President, W.C. Maybury, pointed out that at its inception, Conference members had written eighty percent of the business, and that percentage had since dropped to fifty percent. ${ }^{61}$ Maybury also suggested that his company had left to escape the restrictions of the Conference agreement. ${ }^{62}$ A few years later, in late 1904, the Employers' Liability Assurance Corporation also withdrew, citing its opposition to higher Conference manual rates scheduled for a month later, preferring instead a strategy of reducing expenses, particularly agent commissions. ${ }^{63}$

59. High market concentration can imply monopoly profits, because collusion is easier with a relatively small number of firms, but high market concentration may also occur because some firms are more efficient, and therefore charge lower prices and reap higher profits, than their rivals. See Byeongyong Paul Choi and Mary A. Weiss, "An Empirical Investigation of Market Structure, Efficiency, and Performance in Property-Liability Insurance," Journal of Risk and Insurance 72 (2005): 635-73 (testing both hypotheses and finding support for efficiency hypothesis).

60. Weekly Underwriter, November 22, 1902, 293.

61. Weekly Underwriter, December 6, 1902, 316; and "Liability Situation-Standard's Withdrawal Discussed With Mr. Maybury and Others," Insurance Press, November 26, 1902, 1 .

62. "Liability Conference Loses Detroit Company," The Standard, November 21, 1902, 482.

63. "Employers Liability Conference," The Spectator, November 3, 1904, 229; "Employers' Withdraws From Liability Compact," The Standard, October 28, 1904, 409; and Weekly Underwriter, October 29, 1904, 293, 296. 

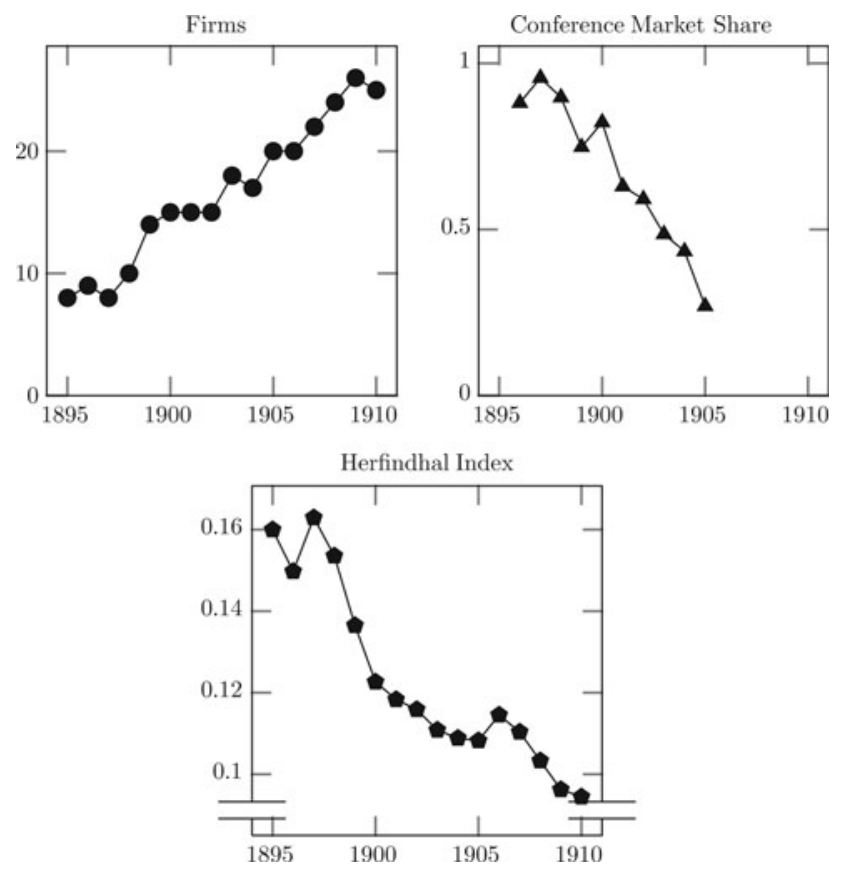

Figure 2. Number of firms, Liability Conference market share, and industry concentration, 1895-1910. Sources: Annual data on liability premiums received by multi-line stock companies as reported in The Insurance Year Book 1901-1902. [Life, Casualty and Miscellaneous] (New York: Spectator Co., 1901), 325-32; The Insurance Year Book 1904-1905 [Life, Casualty and Miscellaneous] (New York: Spectator Co., 1904), 418-28; and The Insurance Year Book 19111912 [Life, Casualty and Miscellaneous] (New York: Spectator Co., 1911), A-260 to A-287. Mutual insurers selling liability insurance are not included in the underlying data. Exits from Conference (see Table 2) are coded by calendar year after the year in which exit occurred.

Price competition from new firms destabilized the Conference's price-fixing efforts. To illustrate, consider how the Conference responded to the entry of the Maryland Casualty Company into the liability insurance market. Shortly after its inception in March 1898, the Maryland Casualty Company, based in Baltimore, had, according to one account, advertised that it was "not bound by compact rates," that is, that it would offer liability insurance at rates below those in the Liability Conference Manual. ${ }^{64} \mathrm{~A}$ few months later, in early May 1898, the Conference had invited Maryland

64. Letter to the Editor, "Cut Rates in Liability Rates," The Spectator, April 14, 1898, 201 (authored by "Liability Underwriter"). 
Casualty, through its President, John Stone, to join the Conference. ${ }^{65}$ Stone refused, pointing to a personality conflict with George Seward, now President of the Fidelity and Casualty Company. ${ }^{66}$

In the summer of 1898, Maryland Casualty offered Travelers liability manager Edwin De Leon a position as its New York agent. De Leon asked Travelers President Batterson for his advice as a polite way to solicit a counter-offer. Batterson refused, ${ }^{67}$ and De Leon soon left for Maryland Casualty. ${ }^{68}$ Soon thereafter, Maryland Casualty started a price war. When De Leon had left Travelers, he had apparently taken "a complete list of [Travelers'] patrons" and was now "approaching them with cut rates." 69

In mid-September, Batterson wrote separately to Conference President Endicott that, in response to the "vicious competition with which we are confronted," the Conference companies "are all apparently asking for special rates on business which they cannot hold at Manual rates. Maybury asks consent to protect his Baltimore business against new comer who has stolen his agent. I am in precisely the same fix in New York. . . . . DeLeon will first go for the risks with which he is familiar, - ours; but he will not spare any Company's business which he can get. He is offering 20 per cent. commission where we have paid only fifteen." 70 Batterson added: "I cannot wait for the Board to act. When the house is on fire, it is not wise to call a town meeting to see what is best to do about it." 71

Batterson soon proposed that the Conference abandon "the rate book for competition purposes and leave each Company to protect its own business

65. "Liability Conference Adjourns," The Standard, May 7, 1898, 531; and "President Stone on Liability Competition," The Standard, December 24, 1898, 670.

66. Batterson to George F. Seward, dated October 7, 1898, Vol. 3, President's Letters, p. 531; Scrapbooks, Letterbooks, \& Miscellaneous, Box 4; President's Interests; Executive, Record Group 2; Travelers Insurance Company, Hartford, CT. Hereafter, PL3 refers to items from this bound volume of letters.

67. J. Batterson to E.W. DeLeon, dated August 6, 1898, PL3, p. 391; and J. Batterson to E.W. DeLeon, August 8, 1898, PL3, p. 393.

68. Weekly Underwriter, September 3, 1898, 121; and "Notes of Insurance Interests," New York Times, September 4, 1898, 20.

69. J. Batterson, to W.C. Maybury et al. (cc: Employers Liability, Fidelity \& Casualty, London \& Guarantee, U.S. Casualty, Union Casualty), dated September 21, 1898, PL3, p. 476.

70. Batterson to G.M. Endicott, Sept. 24, 1898, PL3, p. 479. The term "new comer" is a reference to the Maryland Casualty Company's hiring away of the Baltimore agent for The Standard Life and Accident Co., of which W.C. Maybury was president at the time. Batterson to Geo. F. Seward Esq., Prest., Fidelity \& Casualty Co., October 7, 1898, PL3, p. 531 (referring to how Maryland Casualty President Stone "hired Standard's agent").

71. Batterson to G.M. Endicott, September 24, 1898, PL3, p. 480. 
in any way it sees fit. In fact we cannot do otherwise and hold our agents." 72 He favored continued cooperation "for the sake of combining the experience of the associated Companies in order to determine the pure premium on classified risks. We can work together as against a common enemy and treat each other fairly: but let each Company manage its own business in its own way." 73

Unwilling to wait for a Conference meeting on the issue, Batterson took unilateral action. As he told an agent in Louisville, the Maryland Casualty Company and another non-Conference company, the Frankfort Marine, Accident and Plate Glass Insurance Company, "are on the war path . . . . I have determined for this Company that we will meet their rates if necessary to save our desirable risks. ... [L]ook to your renewals a full month or two before they mature or you will be caught napping." 74

In the first week of October 1898, the Conference temporarily suspended its rules and rates pending a meeting on the issue for the following week. ${ }^{75}$ Conference President Endicott favored dissolution, whereas Seward supported maintaining the Conference rate agreement. ${ }^{76}$ When the Conference finally met, in New York, on October 12, W.T. Dana, the representative of Employers' Liability Assurance Corporation, issued that company's resignation, and then withdrew it, and the story that emerged in the insurance trade press was that of Conference members holding firm. ${ }^{77}$

Yet, less than two weeks after the October 12 meeting, Conference actuary Stewart Marks sent a notice to agents in New York that reminded them of the Conference limit of fifteen-percent commissions and reaffirmed the Conference's authority to take disciplinary action for violation of that rule. ${ }^{78}$ The unstated target of Marks' notice was apparently the

72. Batterson to C.P. Ellerbe Esq., Prest., September 26, 1898, PL3, p. 484.

73. J. Batterson to W.C. Maybury, Esq., Detroit, MI, September 26, 1898, PL3, p. 488; see also Batterson to G.M. Endicott Esq., Chairman \&c., September 26,1898, PL3, p. 490 ("Why can we not send our experience on classified risks to the Bureau, simply giving the amount insured and the loss thereunder to find the pure premium needed to carry the risk, and stop there, so far as rates are concerned.").

74. Batterson to J.B. Pirtle Esq., State Agent, Louisville, KY, September 28, 1898, PL3, p. 511-12; see also Batterson to Horace W. Power Esq., State Agent, Cleveland OH, September 28, 1898, PL3, p. 503 ("Until further instructions are received from this Office, you may govern yourself by the old Manual. We shall try to save our desirable risks from the Maryland Company on the best terms we can make.").

75. Weekly Underwriter, October 8, 1898, 211.

76. Batterson to W.C. Maybury, Esq., Managing Director, Detroit, MI, September 26, 1898, PL3, p. 487.

77. "Liability Companies Hold Together," The Standard, October 15, 1898, 427.

78. Reprinted in "The Liability Situation," The Spectator, October 27, 1898, 185. 
Travelers. Seward, at least, had complained that Travelers had been paying twenty-percent commissions in violation of Conference rules. ${ }^{79}$

By early December 1898 , George Endicott was dead, ${ }^{80}$ and a few weeks later, the Conference members elected George Seward to succeed Endicott as Conference president. ${ }^{81}$ About nine months later, however, in October 1899, the Liability Conference was negotiating with the Maryland Casualty Company over the terms of its joining the Liability Conference. ${ }^{82}$ This was not easy. Because of Maryland Casualty's price war with the Conference members in the prior year, some Conference members appear to have been reluctant to take the company inside. In a letter to A.W. Masters, general manager of London Guarantee and Accident, Travelers President Batterson referred to George Seward's idea that Maryland Casualty President John Stone "“ought not to be admitted until he begins to feels the pressure of losses." Batterson found this suggestion impractical, because that time was "indefinite and unknown." 83

The next day, Batterson wrote to mollify Seward: "We all feel alike in regard to the onslaughts made upon our business by the Maryland; but it has now become a matter of business and not a question of retaliation or sentiment." He added: "Now my esteemed Chairman I want to say that I admire your fighting qualities, and the way you put your fist down sometimes leads me to an earnest prayer for our enemies, but I cannot agree with you that we are justified either in delay, or going back of the date when we opened negotiations by Committee for reasons to sustain that position." 84

A week earlier, Batterson, who apparently had been charged to deal with Maryland Casualty about Conference membership, had written to Maryland Casualty President Stone and given him four reasons for joining Conference. First, "a considerable bulk" of Maryland's business had been drawn from the Conference companies "by reduced rates or otherwise" that were "below the line of safety, and must be unprofitable if continued." Second, a threat: some of the Conference companies had a "strong disposition ... to regain" the business they had lost to the Maryland "regardless of the question of profit or loss." Third, joining the Conference meant that the Maryland's liability policies could be renewed at the increased manual rates, not the lower rates at which they were originally obtained. Finally, the Maryland would benefit from loss-data pooling without paying a

79. Batterson to Geo. F. Seward, October 29, 1898, PL3, p. 547.

80. "Death of the Pioneer of Employers' Liability Insurance in the United States," Weekly Underwriter, December 10, 1898, 331.

81. "Business of the Liability Conference," The Standard, December 24, 1898, 662.

82. Batterson to George F. Seward, October 11, 1899, PL3, p. 822-23.

83. Batterson to A.W. Masters, October 13, 1899, PL3, p. 825-26.

84. Batterson to George F. Seward, October 14, 1899, PL3, p. 834-35. 
proportionate share of past expenses and without contributing the same volume of loss experience as other Conference companies. ${ }^{85}$ Batterson urged Stone to move quickly, writing a few days later that "[e]very day's delay may bring up some new complications at points where agents are more anxious to get business than to preserve harmony among the Companies." 86

Batterson did not mention that absent price competition by a non-Conference company such as Maryland Casualty, it would become easier to preserve the price-fixing features of the Conference Agreement. As Batterson wrote to Seward a few days later: "I am afraid we will not be able to 'set our own house in order' until The Maryland is in the Conference, for so long as that Company is 'outside,' it will be impossible to control the business 'inside." 87 Indeed, Batterson assumed that Stone "knows as well as we do that Conference agreements as to brokerages are being broken right along, and that we cannot easily control that so long as he is outside." 88 By early November, the Maryland Casualty Company had been persuaded inside. ${ }^{89}$ Thereafter, no other company joined the Conference before it abandoned price-fixing in 1906.

\section{B. Defections}

Just as price competition came from non-Conference rivals, it may have also come from fellow Conference members who had covertly defected from the Conference agreement on prices and commissions. Cartel theory emphasizes that cartel members have the incentive to defect, because prices are fixed above the competitive level. Theory also suggests that, when two sellers agree on a price, if either seller can quickly observe the other's defection and respond by "punishing" the first seller by engaging in fullblown price competition, the threat of such punishment may deter defection in the first place. ${ }^{90}$ I have no direct evidence of cheating by Conference companies, in part because the Conference practice of special rating makes it hard to prove such cheating, absent data on the actual premium rates on policies sold by each Conference company.

85. Batterson to John T. Stone, President, October 3, 1899, PL3, p. 810-11.

86. Batterson to Stone, October 6, 1899, PL3, p. 817.

87. Batterson to Geo. F. Seward, Chairman, October 11, 1899, PL3, p. 822.

88. Batterson to A.W. Masters, October 13, 1899, PL3, p. 825.

89. "Maryland Casualty Joins Liability Compact," The Standard, Nov. 18, 1899, 477. For the terms and conditions of entry, see Memorandum of J.G. Batterson \& Jno. T. Stone, October 27, 1899, PL3, p. 868.

90. Jean Tirole, The Theory of Industrial Organization (Cambridge: MIT Press, 1988), $245-53$. 
Under the Conference special-rating procedure, the Conference could sanction the sale of a Conference company policy at a "special rate": a Conference-approved rate below the manual rate for a particular buyer when such a rate was ostensibly needed to prevent a buyer from purchasing liability insurance from a non-Conference company. ${ }^{91}$ Applications for special rates, although initiated by local agents, had to come to the Conference from the home office of the Conference company member, not from the agent directly. ${ }^{92}$ Non-Conference rivals scorned specialrating. In 1904, Aetna Life - a non-Conference liability insurer-reported to its agents that a "large percentage" of Liability Conference policies "are specially rated far below their regular Manual, such special rates being in fact,-when approved by their bureau,-Conference rates." Aetna added that a non-Conference company engaged in the "selfsame procedure . . . is styled 'rate cutting.' Surely this is a distinction without a difference ....".93

We do know that Travelers President Batterson complained that the Conference companies used special rating to protect themselves from competition by other Conference companies. For example, he wrote to Conference arbitrator Marks in 1898 that "[v]ery few of the special ratings so far seem to be called for by outside competition, or by a conviction that the rate is excessive. No one can deliberately look over the list of these cases without being convinced that the effect, if not the purpose, is to protect the risk from competition by Conference companies. . . . [T]he business is being rapidly tied up by special rates and we will soon have to consult the acts of the Special Rating Committee rather than the Manual. One special rate of necessity leads to another, because all in the same business will demand it." 94 A few years later, in April 1900, Batterson complained: "To keep watch of the special rates applied for, ascertain (if possible) whether the application is justified by the rules and if not to file a protest, consume not a little time every day." It was particularly hard when "the rate is all right in the application, but the cut is

91. Batterson to Stewart Marks, July 7, 1898, PL3, p. 367; and Batterson to John T. Stone, October 13, 1899, with attached copy of special rate request from Travelers' agent, PL3, p. 829-30; see also "Liability Compact's Rule on Special Rates," The Standard, December 9, 1899, 542 .

92. Batterson to E.W. DeLeon, August 5, 1898, PL3, p. 390; and Batterson to DeLeon, August 8, 1898, PL3, p. 394.

93. Aetna Life Insurance Co., Accident \& Liability Dept., “'Special Rates' or 'Cut Rates': A Distinction Without A Difference," Monthly Letter to Our Agents, Oct. 1904, Aetna Insurance Co., Hartford, CT.

94. Batterson to Stewart Marks Esq., Chief of Bureau, October 28, 1898, PL3, p. 542; and Batterson to C.P. Ellerbe, Esq., Prest., Union Casualty \& Surety Co., November 3, 1898, PL3, p. 551. 
covered up by a rider." ${ }^{95}$ Other Conference company managers may have shared this view.

Moreover, Conference company managers may also have been resigned to partial fealty from insurance agents working for Conference companies, who tended not to want to lose any sale, and the accompanying commission, to a fellow Conference member. As case studies in other industries have suggested, rivalry among brokers or independent sales agents may be an important source of the instability of price-fixing agreements, or at least a way that company managers can explain indications of defection from such agreements in way that enabled continued cooperation among them. ${ }^{96}$ Traveler's Batterson pointed to this difficulty for the Conference agreement: "[T] he ordinary agent considers it a mark of genius to steal a risk from an associate Company. . . Almost every mail brings advice of some risk lost to an associate Company by means forbidden. "The agent made it to our advantage" is about as near as we can get to particulars." Batterson, however, also blamed the companies. Although a company could "cure this by refusing to take the risk or to pay the commission on stolen business," the agent "wants business, and will work his territory against all comers; he will rebate to the extent of his full commission to get a risk on his books, and then will urge the payment of illegitimate claims to keep it the next year. We all believe this to be true, but submit rather than be disagreeable about it, and have a row with our agent." 97

\section{State Anti-Trust}

In theory, Liability Conference members risked liability under state antitrust or competition law, because of the Conference's agreement on premium rates and commissions. There appears, however, to be no reported instance of legal action against a Conference company for violating state antitrust or competition law because it participated in the Conference. Moreover, there is only weak evidence that such laws caused the

95. Batterson to A.W. Masters, April 12, 1900; Vol. 4, President's Letters, p. 51-52; Scrapbooks, Letterbooks, \& Miscellaneous, Box 4; President's Interests; Executive, Record Group 2; Travelers Insurance Company, Hartford, CT. Hereafter, PL4 refers to record items from this bound volume of letters.

96. Mark R. Wilson, "Gentlemanly Price-Fixing and its Limits: Collusion and Competition in the U.S. Explosives Industry during the Civil War Era," Business History Review 77 (2003): 216-18; and David Genesove and Wallace P. Mullin, "Rules, Communication, and Collusion: Narrative Evidence from the Sugar Institute Case," American Economic Review 91 (2001): 393.

97. J. Batterson to W.C. Maybury, Esq., September 26, 1898, PL3, p. 486. 
Conference companies to stop selling liability insurance in particular states, or affected how long those companies stayed in the Conference.

In public, the Liability Conference responded to antitrust concerns by imitating fire insurers, who had argued that classic antitrust concerns about price fixing did not apply to them, because the insurance market had low barriers to entry and needed rate setting to reduce the insolvency risk borne of rate cutting. ${ }^{98}$ In 1897, Richard Loper, the general manager of The Guarantor's Liability Indemnity Company, and not a Conference member, charged that the Liability Conference's rate-setting activities made it a trust. ${ }^{99}$ Conference President George Seward responded by stressing that the Conference had formed to avoid "ruinous" competition, not to "drive any competitor out of the field." He added: "And might not such combinations be styled 'combinations to maintain solvent conditions' instead of "combinations in restraint of trade?"'100

In private, Travelers President Batterson, for one, worried about state antitrust law. In October 1897, Batterson had complained to Conference arbitrator Marks about agents who had discussed with policyholders the substance of Conference agreement disputes, "This has been done in numerous cases, and in a way which gives direct evidence of a combination to fix prices for rates for insurance held, which has been held by Courts in some states to be unlawful." If the Conference could not stop agents from discussing complaints to policyholders, then "we are all at sea and the result will be disasterous [sic]." 101

The available evidence, however, does not clearly show that any worry about state competition law caused a Liability Conference company to stop selling liability insurance in any particular state. Although most states enacted antitrust statutes from 1889 through 1914, only a few states enacted antitrust statutes that expressly referred to insurance. ${ }^{102}$

98. See, for example, Address of E.C. Irwin, President, National Board of Fire Underwriters, in Chicago Conference On Trusts: Speeches, Debates, Resolutions, List of Delegates, Committees, Etc.; Held September 13th, 14th, 15th, 16th, 1899 (Chicago: Civic Federation of Chicago, 1900), 438, 450.

99. "The Alleged Trust in Liability Insurance," The Spectator, April 29, 1897, 209 (quoting Loper as stating: "I am fighting the insurance trust, and the trust is trying to destroy my company."').

100. George F. Seward, "Liability Insurance," in The Insurance Year Book. 1897-8 [Life and Miscellaneous] (New York: Spectator Co., 1897), 237-38. For similar arguments, see "The Alleged Trust in Liability Insurance," The Spectator, April 29, 1897, 209; and "The Liability Conference," The Standard, May 8, 1897, 514.

101. Batterson to Stewart Marks, Esq., Chief, Bureau of Statistics \& Arbitration, October 11, 1897, PL3, p. 88-89.

102. "Statutes and Digested Decisions of Federal, State, and Territorial Law Relating to Trusts and Industrial Combinations," prepared by Jeremiah W. Jenks, Expert Agent, in 
Moreover, from 1896 through March 1906 - the tenure of the Liability Conference - state antitrust statutes in only Kansas (1889) and Nebraska (1897) expressly covered more than fire or property insurance, ${ }^{103}$ and courts in only Iowa (1897) and Mississippi (1897) declared that insurance fell within the ambit of other words in their state antitrust statutes. ${ }^{104}$ Although a few state courts opined to the contrary, ${ }^{105}$ in most states, the courts did not publish opinions concerning whether their state's antitrust statute covered insurance. State courts in Indiana (1884) and Illinois (1905), however, had opined that a combination to fix fire insurance rates amounted to a restraint of trade that violated state common law. ${ }^{106}$

Industrial Commission, Trusts and Industrial Combinations, H.R. Doc. 476, 56th Cong., 1st Sess. (Washington: Government Printing Office, 1900), vol. 2, pt. 1, pp. 5-264; Laws on Trusts and Monopolies (Washington: Government Printing Office, rev. ed. 1914), 41361; and Clarence W. Hobbs, "State Regulation of Insurance Rates," Proceedings of the Casualty Actuarial Society 11 (1925): 227-63 (digest of state statutes affecting insurance).

103. Act of March 2, 1889, ch. 257, § 1, 1889 Kan. Sess. Laws 389, 389 (covering efforts to "control the cost or rate of insurance"); and Act of - , 1897, ch. 79, § 1, cl. 3, 5, 1897 Neb. Laws 347, 347-48 (covering combinations "[t]o prevent competition in insurance, either life, fire, accident, or any other kind").

104. American Fire Insurance Co. v. State, 22 So. 99, 103-04 (Miss. 1897) (fire insurance rate-making association was effort to control a "business" under state antitrust statute); and Beechley v. Mulville, 70 N.W. 107, 109 (Iowa 1897) (insurance is "commodity" under 1890 state antitrust statute).

105. See Aetna Insurance Co. v. Commonwealth, 51 S.W. 624, 626 (Ky. 1899) (right to enter into an insurance contract is not included in the word "property"); Queens Insurance Co. v. State, 24 S.W. 397, 401 (Tex. 1893) (fire insurance not covered by terms "trade", "commerce," or "commodity"), abrogated by Act of April 30, 1895, ch. 83, 1895 Tex. Gen. Laws 112, 113-14; see also Biennial Report of the Attorney General of the State of Illinois (Springfield: Phillips Bros., 1899), 228 (opinion, dated October 8, 1897, that state antitrust act of 1891 "does not apply to insurance companies," where that act covered efforts to fix the price of "any article of merchandise or commodity" or to limit the quantity of any "article, commodity or merchandise" sold in the state, Act of June 11, 1891, § 1, 1891 Ill. Laws 206, 207). In Ohio, see Runck v. Cloud, 8 Ohio N.P. 436, 1901 WL 19368 (Ohio Super. Ct. 1901) (insurance not covered by Ohio antitrust statute); State ex rel. Taylor v. Ross, 16 Ohio Dec. 704, 1906 WL 1575 (Ct. Common Pleas 1906) (fire insurance covered by Ohio antitrust statute) (decided May 5, 1906); and State v. Bovee, 17 Ohio Dec. 663, 1907 WL 719 (Ct. Common Pleas 1907) (insurance not covered by Ohio antitrust statute).

106. People v. Aachen \& Munich Fire Insurance Company of Germany, 126 Ill. App. 636 (4th Dist. 1905) (reversing demurrer in a suit by the Illinois Attorney General against 110 fire insurance companies for common law conspiracy to fix fire insurance rates in St. Clair and Madison counties); and Metzger v. Cleveland \& Adams (Ind. Superior Ct., Marion County, decided April 1884), in Insurance Law Journal 28 (1899): 176-82. But see Continental Ins. Co. v. Board of Fire Underwriters of the Pacific, 67 F. 310, 322 (C.C.N.D. Cal. 1895) (fire underwriters board not common law conspiracy, because board formed for "trade reasons, in which the co-operation of all companies was undoubtedly desired," not specifically to intermeddle in plaintiff"s business). 
Moreover, although state legislatures, largely in the Midwest and the South, also enacted so-called anti-compact statutes that specifically banned cooperative rate setting for insurance policies, at least up through 1910, most of these laws covered only fire insurance or fire insurance companies. ${ }^{107}$ Only the statutes in Georgia (1891) and Alabama (1897) were not limited on paper to any particular kind of insurance or insurance company. ${ }^{108}$

Of the states just identified, five experienced legislative or judicial action during the Conference's tenure that arguably raised the odds that the Conference agreement would be found to violate that state's law: Alabama (1897); Iowa (1897); Nebraska (1897); Mississippi (1897); and Illinois (1905). If a Conference firm worried enough about a state's legislative or judicial action in that year, we should expect that firm to stop receiving liability insurance premiums in that state soon thereafter - a proxy for liability insurance sales - but not stop selling other types of insurance it had been selling there.

Although there are limited available state-level data on liability insurance premiums, those data do not indicate significant movement out of Alabama, Iowa, and Nebraska in a three-year period after 1897 (Table 3). Unfortunately, the relevant data for Mississippi are missing. Any causal inference concerning the 1905 Illinois appellate court decision

107. Act of May 4, 1885, 1885 Ohio Laws 231 (amended by Act of May 1, 1891, 1891 Ohio Laws 485-86); Act of Aug. 29, 1885, ch. 93, § 1, 1885 N.H. Laws 289, 289; Act of March 28, 1893, ch. 285, 1893 Me. Acts 339 (repealed by Act of Feb. 18, 1895, c. 26, 1895 Me. Acts 24); Act of -, 1897, ch. 81, § 1, 1897 Neb. Laws 354; Act of March 1, 1898, ch. 644, § 1, 1898 Va. Acts 683, 683 (effective July 1, 1898); Act of March 7, 1899, No. 39, § 1, 1899 S.C. Acts 59, 59; Act of March 2, 1900, ch. 680, 1899-00 Va. Laws 718; Act of July 11, 1900, No. 110, 1900 La. Laws 172; Act of March 9, 1903, ch. 158, 1903 S.D. Laws 183; Act of March 4, 1905, ch. 424, 1905 N.C. Laws 429; Act of April 17, 1905, ch. 479, § 1, $1905 \mathrm{Tn}$. Laws 1019, 1019. A few covered fire and other types of property insurance. Act of April 3, 1896, ch. 22, § 1, 1896 Iowa Laws 31; and Act of March 13, 1897, ch. 65, § 9, 1897 Wash. Sess. Laws 105, 110. Two more states covered fire, marine, and marine and inland insurance companies. Act of June 28, 1887, No. 285, §§ 1-2, 1887 Mich. Pub. Acts 384, 384-85; and Act of April 27, 1897, ch. 356, 1897 Wis. Sess. Laws 908. Excerpts of some of these statutes appear in "Anti-Compact Laws," Hayden's Annual Cyclopedia of Insurance in the United States 1908-1909 (Hartford: Insurance Journal Co., 1909), 3043. Excluded here are provisions that were part of or added to antitrust statutes.

108. Act of Oct. 21, 1891, No. 745, § 1, 1891 Ga. Laws 206 (unlawful for "any insurance company or companies" to enter into arrangement with "any other insurance company or companies ... for purpose of, or that may have tendency or effect of, preventing or lessening competition in the business of insurance transacted in this state"); and Act of Feb. 18, 1897, 1897 Ala. Laws 1428 (providing policyholder to recover, in event of loss or damage, an additional twenty-five percent of the actual loss upon proving that the insurer, at the time of the policy or before trial, was "in any way connected" with premium rate-fixing). 
Table 3. Number of Liability Conference Firms Collecting Liability Premiums in Selected States, 1897-1900.

\begin{tabular}{lcccc}
\hline & 1897 & 1898 & 1899 & 1900 \\
\hline Alabama & 5 & $4^{\mathrm{a}}$ & 4 & 4 \\
Iowa & - & $5^{\mathrm{a}}$ & $5^{\mathrm{b}}$ & 5 \\
Nebraska & - & 4 & - & 5 \\
Mississippi & - & - & - & - \\
\hline
\end{tabular}

Sources: The Insurance Year Book 1901-1902 [Life and Miscellaneous] (New York: Spectator Co., 1901), 421, 427, 435; The Insurance Year Book 1900-1901 [Life and Miscellaneous] (New York: Spectator Co., 1900), 391, 396, 403; The Insurance Year Book 1899-1900 [Life and Miscellaneous] (New York: Spectator Co., 1899), 363, 368-69, 375; and The Insurance Year Book 1898-9 [Life and Miscellaneous] (New York: Spectator Co., 1898), 335, 344.

Notes: "-" indicates missing data. Maryland Casualty Company is not treated as a Conference member until 1900.

${ }^{a}$ Not counted is the Standard Life and Accident Company, which received accident insurance premiums, received zero liability premiums, and incurred liability losses.

${ }^{b}$ Standard Life and Accident Insurance Company resumed collecting liability premiums, whereas the Fidelity and Casualty Company received some accident insurance premiums and zero liability premiums.

is complicated by the close proximity of this decision to the Conference's end in 1906. ${ }^{109}$

Moreover, in September 1899, the Union Casualty and Surety Companya Liability Conference member at the time-announced that it had agreed to transfer the liabilities of all its unexpired liability insurance policies to a non-Conference rival, the Maryland Casualty Company, along with its reinsurance reserve on those unexpired policies. ${ }^{110}$ Although reported in some newspapers as simply a notable business deal, at least one newspaper, the St. Louis Republic, reported that Union Casualty had initiated talks with Maryland Casualty in July 1899, because Union Casualty feared that the Missouri attorney general would sue it for participating in the Liability Conference. ${ }^{111}$ (As a Missouri corporation, Union Casualty

109. People v. Aachen \& Munich Fire Insurance Company of Germany, 126 Ill. App. 636 (4th Dist. 1905) (opinion filed September 18, 1905). Petition for rehearing was denied on February 28, 1906, less than a month before the Conference's end as a cartel. Ibid.

110. “A Big Scoop By the Maryland Casualty," United States Review, September 7, 1899, 157; see also "A Deal Completed: Western Business Absorbed by the Maryland Casualty Company," The Sun (Baltimore), September 2, 1899, 12; and "Insurance Companies Unite: The Maryland Casualty and the Union Casualty of St. Louis," New York Times, September 3, 1899, 12.

111. "Big Insurance Deal Is Consummated: Union Casualty Company of St. Louis Sells Its Unexpired Liability Risks," St. Louis Republic, September 2, 1899, pt. II, 1. When asked whether it struck the deal to avoid antitrust prosecution, company general manager Theodore 
could not avoid a lawsuit by the Missouri attorney general simply by not selling liability insurance business in that state.) I have no primary evidence to corroborate this assertion.

Finally, state antitrust laws seem more plausible as a pretext for Travelers' exit from the Liability Conference. In April 1899, as state antitrust legislation and lawsuits proceeded against fire insurance companies in Missouri and Arkansas, ${ }^{112}$ Travelers President Batterson wrote to Conference President Seward: "I believe . . . that the Missouri and the other like laws will be sprung upon us, and if fought out in the courts we will be beaten sure." He announced that Travelers "decides to withdraw from the Conference so far as rates are concerned, and remain for the purpose of comparing and combining experience." He complained that the Conference companies "have the credit for" liability insurance premium rates, even though non-Conference companies really controlled rates through their rate-cutting. Accordingly, he argued, the Conference companies would be better off just pooling their loss-experience data "as we can under any other system which it is so strongly made the subject of adverse legislation."113

Despite this declaration, Travelers did not exit the Conference. It remained inside for over a year more. In January 1900, Batterson declared that because of the Conference practice of special rates, Travelers' "present intention" was to leave the Liability Conference at its

Gaty reportedly replied: “'That is a question I do not care to answer."” Ibid. At least three midwestern newspapers based their own stories on the report in the St. Louis Republic. See "Dodging Anti-Trust Law: Union Casualty Company of St. Louis Transfers Business to a Maryland Corporation," Morning World-Herald, September 2, 1899, 2 (Omaha newspaper); "Takes the Cash Along: Casualty Company Executive Departs for Fear of Prosecution," Duluth News Tribune, September 2, 1899, 1; and "Big Insurance Deal: Brought About by Operation of the Missouri Anti-Trust Law-Nature of the Transaction," Dallas Morning News, September 2, 1899, 3; see also New York Times, September 3, 1899, 12 ("Fear that Attorney General Crow would institute proceedings against the Union Casualty Company under the anti-trust laws of Missouri is the ascribed cause of the deal between the Union and Maryland Casualty Companies."). But see "A Big Scoop By the Maryland Casualty," United States Review, September 7, 1899, 157 ("Fears that the Attorney-General of Missouri would proceed against the Union for violation of the anti-trust laws is one of the motives assigned by rumor as the reason for the re-insurance. There is not much credence put in this, however.").

112. For Missouri, see Piott, Anti-Monopoly, 37-51. For Arkansas, see Act of March 6, 1899, Act XLI, § 1, 1899 Ark. Acts 50, 50-55; "No Insurance in Arkansas: Under the Anti-Trust Law 63 Companies Are Sued for $\$ 315,000$ Each and Are Taking No More Risks," New York Times, April 1, 1899, 2; and State v. Lancashire Fire Ins. Co., 51 S.W. 633 (Ark. 1899).

113. Batterson to Geo. F. Seward Esq., Chairman \&c., April 12, 1899, PL3, p. 639. 
next meeting. ${ }^{114}$ Around this time, Batterson was also frustrated with Travelers' liability business. ${ }^{115}$ A few days later, at the February 27 Conference meeting in Hartford, the Conference apparently took up the matter of special-rating abuse $\mathrm{e}^{116}$ and, according to the Standard, voted that it would no longer require Conference members to abide by manual rates. The Conference's Bureau of Arbitration and Statistics would, therefore, be renamed the Bureau of Statistics, and Stewart Marks, formerly the Conference arbitrator, now had the title of actuary. The main reason for this change, reported the Standard, was "the embarrassment experienced by some companies in states which have anti-trust laws."117

Although what happened in that meeting is unclear, the Conference agreement apparently retained some price-fixing features, because by April, Batterson was again giving notice of Travelers' "immediate withdrawal" from the Conference, again because of the special rating system. ${ }^{118}$ When Conference President Seward tried to pressure Batterson to stay in the Conference, in part on the ground that the Conference had tried to accommodate Travelers' concerns at the February 27 meeting, Batterson would have none of it: "That the original agreement 'was abandoned mainly out of regard for our difficulties' is news to me. My recollection is that the agreement was abandoned for legal reasons which affected all alike." 119

By August, however, Batterson still had not "confirmed our resignation from the Conference for fear of its effect upon our own agents, who would immediately make demands that we could not grant."120 Another reason for the delay was that at the time, Michigan Insurance Commissioner $\mathrm{H}$. H. Stevens was auditing Travelers' liability insurance business; accordingly, Batterson told Seward to put "further action about Conference matters" on hold, and promised not to "withdraw the rate books from our agents." 121

Several weeks later, Batterson publicly criticized Commissioner Stevens, who after completing his audit, billed Travelers what Batterson considered to be an exorbitant amount for expenses and, when Travelers refused to pay,

114. Batterson to Seward, January 15, 1900, PL3, p. 961; see also Batterson to Marks, January 18, 1900, PL3, p. 963; and Batterson to Stone, January 27, 1900 PL3, p. 972.

115. James G. Batterson, President, to J.G. Batterson, Jr., Gen. Mgr., Travelers Ins. Co. N. Y., December 13, 1899, PL3, p. 927-28.

116. "Liability Conference in a Protracted Session," The Standard, March 3, 1900, 13.

117. "Liability Rates Are No Longer Mandatory," The Standard, March 10, 1900, 11.

118. Batterson to Stewart Marks, April 11, 1900, PL4, p. 47.

119. Batterson to Geo. F. Seward, April 14, 1900, PL4, p. 54.

120. Batterson to Seward, August 18, 1900, PL4, p. 169.

121. Batterson to Seward, August 25, 1900, PL4, p. 178. 
allegedly threatened Travelers' business in Michigan. ${ }^{122}$ A few days later, George Seward wrote to the Journal of Commerce and Commercial Bulletin, which had similarly criticized Commissioner Stevens, to defend Stevens' reputation and, in so doing, suggested that Batterson had the discretion of a "bull in a china shop" and had "Irish blood in his veins." 123 In a letter to the Journal, Batterson replied to Seward's comments. ${ }^{124}$ That same day, Batterson wrote a letter to Conference Actuary Marks in which he "confirm[ed]" Travelers' withdrawal from the Conference. ${ }^{125}$ Hearing of this news, Seward privately celebrated: "We are all to be congratulated ... on having at last the Travelers on the outside, their uncertain attitude having long been a cause of embarrassment."126

When Batterson died less than a year later, ${ }^{127}$ Sylvester Dunham became Travelers' president. Among the congratulatory letters, Dunham received one from Maryland Casualty President John Stone, who observed that he had "always thought" that Batterson's exit from the Conference had been "largely influenced by personal feeling toward one of the Conference members," an apparent reference to Seward. And then, Stone invited Dunham to have Travelers return to the Conference. Dunham quickly wrote back to refuse: "I can imagine a conference of liability companies, conducted in such a way as to be extremely useful to all its members, and I am by no means hopeless that at some time in the future such an organization will exist and be participated in by the officers of this

122. "Michigan's Insurance Supervision Exposed: How the Insurance Commissioner Makes Examinations," Journal of Commerce and Commercial Bulletin, September 21, 1900, 1 (quoting statement of Batterson, which includes itemized bill of expenses, dated September 13, 1900); and "Travelers Examined: Another Raid on the Insurance Company," Hartford Courant, September 22, 1900, 5 (same).

123. "Mr. Seward on Insurance Examinations," letter from Geo. F. Seward to editor, dated September 22, 1900, in Journal of Commerce and Commercial Bulletin, September 25, $1900,4$.

124. "Mr. Batterson Replies to Mr. Seward," Journal of Commerce and Commercial Bulletin, September 26, 1900, 9 (letter to editor, dated September 25, 1900).

125. Batterson to Stewart Marks Esq., Actuary, \&c., September 25, 1900, PL4, p. 197.

126. George F. Seward to Hon. W.C. Maybury, Standard Life \& Accident Co., September 27, 1900, in Seward Papers, New York Historical Society, Box 4, Folder 10. On October 6, 1900, the Standard announced the news that Travelers had left the "Liability Compact," pointing to Seward's reference to Batterson as a bull in a china shop as "the chief reason of [sic] the rupture," but also mentioning Batterson's concern about the special rating practice among Conference members. "Travelers Quits Liability Compact After All," The Standard, October 6, 1900, 336.

127. "Travelers' 'Grand Old Man' Is Dead," The Standard, September 21, 1901, 251; and "James G. Batterson: Death Came at Early Hour To-day," The Hartford Courant, September $18,1901,1$. 
Company with dignity and self respect." ${ }^{28}$ For Dunham, it seems, the Liability Conference was no longer useful to Travelers' liability insurance business. Dunham did not mention state antitrust law.

\section{Liability Loss Reserve Regulation}

This section develops the idea that state regulation of liability loss reserves partly explains the Conference's fall, because Conference companies had valued Conference membership in part as a credible signal to buyers that those companies had lower insolvency risk than their non-Conference rivals. ${ }^{129}$ To make this signal credible, Conference companies had to show that Conference manual rates reflected better estimates of liability risk, as a result of Conference information pooling. When Michigan became the first state to regulate liability insurers' loss reserves in 1901, the Conference faced a competing signal of insolvency risk, and the Conference became more interested in securing more favorable liability loss reserve regulation. Several key states enacted such regulation in 1905, and the Conference officially abandoned price fixing less than a year later. Causal inference here is complicated, because Conference members might have substantially varied in how much they valued Conference membership as a solvency signal, particularly as compared to other reasons they had for joining the Conference. Still, the available evidence is consistent enough with this causal story to warrant further research.

\section{Conference Membership as Solvency Signal}

Since the Liability Conference's inception, the Conference companies appear to have stressed the connection between Conference membership and lower insolvency risk. As C.P. Ellerbe, then ex-president of the Union Casualty and Surety Company, wrote in a letter to George Seward in late September 1899, "I am more convinced the Liability Conference ought to be maintained, even if the agreement as to rates is not always well kept. For nearly four years the agents have been preaching the solvency of the Compact Companies and the insolvency of

128. John Stone, President, Maryland Casualty Company, to Mr. S.C. Dunham, Harford Conn., October 17, 1901, and Dunham to Stone, October 18, 1901; and Letters of Congratulation on His Election as President of the Travelers Insurance Co.; 100th Anniversary; Communications, Record Group 8; Travelers Insurance Co., Hartford, CT.

129. It is not clear whether buyers did receive and act upon such a signal. This account, however, only requires that Conference company managers believed that buyers could and would. 
non-Compact Companies. To terminate the Conference now would be to place the Conference Companies in an awkward position."130

Accordingly, when the Liability Conference issued its third rate manual in May 1901, the Conference companies touted it as the product of careful calculations based primarily on Conference members' pooled lossexperience. ${ }^{131}$ Indeed, a few months earlier, George Seward's Fidelity and Casualty Company had boasted in the company's monthly bulletin that this manual would be "a work which will hereafter be, to intelligent liability underwriters, what the mortuary tables are to life underwriters." 132 A month later, an item in the company bulletin stressed that the Fidelity and Casualty's contribution to the "expense of tabulating experience, including the cost at the home office and its share of conference expenses, may reach the large sum of $\$ 100,000 . " 133$ When the manual was finally published, the Standard observed that the Conference companies stressed how the Conference had used "scientific principles" in writing the manual. 134

Buyers could perceive such claims as credible, in part because the Conference adopted in the 1901 manual a credible method for calculating liability premium rates developed by the aptly-named Frank E. Law, of the Fidelity and Casualty Company. ${ }^{135}$ A mechanical engineer by schooling, ${ }^{136}$ Law discovered that, even after collecting loss-experience data from all the Liability Conference members, there were still not enough data to produce separate liability-risk-sensitive premium rates for the thousands of industry-specific risk classifications on a state-by-state basis, even though liability risk varied with the law of each state. ${ }^{137}$

To solve this problem, Law aggregated loss data for all the states, and, on that basis, fixed a base premium rate for each of many industry-specific risk classifications. This rate included a markup for administrative expenses

130. C.P. Ellerbe to Geo. F. Seward, Esq., September 22, 1899, Folder 2, Box 4, Seward Papers, New York Historical Society. In March 1899, C.P. Ellerbe had been replaced as company president. "Notes of Insurance Interests," New York Times, March 9, 1899, 14.

131. "New Book of Liability Rates Issued," The Standard, May 4, 1901, 435.

132. "Liability Rates," Monthly Bulletin of the Fidelity and Casualty Company 6 (February 1901): 19.

133. "Liability Conference," Monthly Bulletin of the Fidelity and Casualty Company 6 (March 1901): 35

134. "Salient Features of Liability Manual," The Standard, May 11, 1901, 461.

135. Frank E. Law, A Method of Deducing Liability Rates (New York: Spectator Co., 1908).

136. Who's Who in Insurance: An International Biographical Dictionary and Year Book (New York: Singer Co., 1908): 182.

137. Law, Method, 3 ("In some States not more than three or four of the 950 classifications is written. In all, out of the possible 47,500 classifications that may be written, there is experience on about 3,000."). On data the Conference collected, see Otis, "The Bureau," 261. 
and profit. Then, he derived a "counter-differential" for each state-a number that one could use to adjust the base premium rate for any risk-classification. ${ }^{138}$ For employers' liability insurance, a state's counter-differential, in theory, represented the combination of two components of employer liability risk unique to each state: (1) physical hazard, "exposure to danger to doing work, in methods of doing work, in kind of machinery used, in precautions taken against the occurrence of accidents, and in character and intelligence of employees"; and (2) legal hazard,"the laws and judicial decisions and the attitude of the community, courts, and juries toward the question of the relations between master and man." 139

Table 4 sets forth the counter-differentials for each state for 1908. Using these differentials was simple. For example, if the premium rate for machine shops for the country as a whole was $\$ 0.45$ per $\$ 100$ of payroll, then the machine-shops rate for Texas is that rate $(\$ 0.45)$ multiplied by the Texas differential (2), or $\$ 0.90$ per $\$ 100$ of payroll. After 1901, Conference manuals contained a table of state counter-differentials for certain risk classifications. ${ }^{140}$ Each state counter-differential rested on the premise that future liability exposure would track past experience, and that therefore the actuary had to raise or lower that counter-differential manually to reflect recent changes in state law that would not yet be reflected in the Conference's pooled loss data. ${ }^{141}$ Still, Law's method provided Conference companies with arguably better estimates of liability risk. Just as important, his method made credible the efforts to persuade buyers that a Conference company's liability policy carried less insolvency risk, albeit only if buyers also believed that the company usually sold that policy according to the Conference manual premium rate.

138. Law, Method, 22-23. To produce this number, Law assumed a base loss-cost of 1 for the country as a whole. For each state, he then multiplied the mean premium rates for the country as a whole by the payrolls for the various risk classifications in each state, as well as for total payroll in the state. This resulted in a "pure premium" income for every risk classification in the state, plus one more for the state as a whole. Law divided this pure premium income into the losses for each risk classification in the state, which produced the "pure" or "normal" loss-ratio for every risk classification in the state, plus another for the state as a whole. Finally, Law divided the normal loss ratio for each state (and for each individual risk classification therein) by the normal loss ratio for the country as a whole. Ibid.

139. Frank E. Law, "Liability Insurance: Premium Rates" in The Business of Insurance: A Text Book and Reference Work Covering All Lines of Insurance, vol. 2, ed. Howard P. Dunham (New York: Ronald Press Co., 1912), 255.

140. Manual of Liability Insurance Containing the Rules, Instructions, Rates and Classifications adopted by the Conference of Liability Companies and amended to January 1, 1905, 24.

141. Law, Method, 23. 
Table 4. State Counter-Differentials for Employers' Liability

\begin{tabular}{|c|c|c|c|c|c|}
\hline Alabama & 1.20 & Louisiana & 0.70 & Ohio & 0.80 \\
\hline Arizona Territory & 2.00 & Maine & 1.00 & $\begin{array}{l}\text { Oklahoma } \\
\text { Territory }\end{array}$ & 2.00 \\
\hline Arkansas & 1.33 & Maryland & 0.70 & Oregon & 0.80 \\
\hline California & 1.00 & Massachusetts & 1.00 & Pennsylvania & 1.00 \\
\hline Colorado & 2.00 & Michigan & 0.60 & Rhode Island & 1.33 \\
\hline Connecticut & 0.60 & Minnesota & 1.33 & South Carolina & 1.20 \\
\hline Delaware & 1.33 & Mississippi & 0.80 & South Dakota & 2.00 \\
\hline $\begin{array}{l}\text { District of } \\
\text { Columbia }\end{array}$ & 0.90 & Missouri & 1.33 & Tennessee & 2.00 \\
\hline Florida & 0.60 & Montana & 0.80 & Texas & 2.00 \\
\hline Georgia & 1.20 & Nebraska & 1.33 & Utah & 2.00 \\
\hline Idaho & 2.00 & New Hampshire & 1.00 & Virginia & 0.70 \\
\hline Illinois & 1.33 & New Jersey & 0.70 & Vermont & 1.00 \\
\hline Indiana & 1.20 & $\begin{array}{c}\text { New Mexico } \\
\text { Territory }\end{array}$ & 2.00 & Washington & 2.00 \\
\hline Indian Territory & 2.00 & Nevada & 2.00 & West Virginia & 0.70 \\
\hline Iowa & 1.33 & New York & 1.00 & Wisconsin & 1.33 \\
\hline Kansas & 2.00 & North Carolina & 1.20 & Wyoming & 2.00 \\
\hline Kentucky & 1.33 & North Dakota & 2.00 & & \\
\hline
\end{tabular}

Source: Frank E. Law, A Method of Deducing Liability Rates (New York: Spectator Co., 1908) (chart 2).

\section{Liability Loss Reserve Regulation as a Competing Solvency Signal}

If Conference companies valued Conference membership as a solvency signal, we should expect that they would value that signal less as states began regulating liability loss reserves, because company compliance with such regulation provided a competing signal of company solvency. Although companies selling liability insurance had been subject to general minimum capital requirements, ${ }^{142}$ by the 1890 s, only a few states had enacted special deposit requirements for liability insurers, ${ }^{143}$ and no state had set minimums for liability loss reserves.

142. See, for example, Massachusetts Insurance Act of 1887, ch. $214, \S 31,1887$ Mass. Laws 776, 790.

143. Act of May 19, 1894, § 1, 1894 Ohio Laws 352 (requiring out-of-state liability insurance companies, but not in-state liability insurers, to deposit not less than $\$ 50,000$ in certain securities with the Ohio superintendent of insurance "for the benefit, security and protection of the policy-holders of the company residing within this state"); Act of Feb. 18, 1897, No. 614, § 8, 1897 Ala. Laws 1377, 1381-82 (state-administered "Liability Reserve" charging liability insurers a minimum of $\$ 300$ for each pending lawsuit against a company's 
Although the early liability insurers resisted these deposit requirements, they appear to have had little success. For example, in 1894, Travelers had joined with Fidelity and Casualty, Union Casualty and Surety, and the Standard Life and Accident Company of Detroit to thwart passage of Ohio legislation requiring out-of-state liability insurers to make a $\$ 50,000$ deposit to do business in the state. ${ }^{144}$ In public, insurer objections to the then-proposed legislation included that it discriminated against out-of-state insurers, and that it was prohibitively expensive, particularly if other states adopted the same policy. ${ }^{145}$ Privately, the insurers feared that other states would follow Ohio's lead, and then, as Batterson put it to Seward, "we will none of us have money enough to make the circuit."146 And they strongly suspected that the statute was a protectionist measure to aid Ohio's in-state insurance companies. ${ }^{147}$

When their efforts failed, and the bill became law, the liability insurers went to court. On March 12, 1895, the Fidelity and Casualty Company filed a petition in Circuit Court, Franklin County, against the Ohio superintendent of insurance, arguing that Ohio's 1894 deposit requirement violated provisions of the Ohio State Constitution. ${ }^{148}$ Although Fidelity and Casualty was the only nominal plaintiff, the litigation in Fidelity \& Casualty Co. v. Hahn was, like the failed lobbying effort, coordinated with Travelers, Standard Life and Accident, and Union Casualty and Surety. Those insurers had waited until early 1895 , when their licenses to do business in Ohio were set to expire, ${ }^{149}$ and then demanded

policyholders "for which it may be liable in the lower court and $\$ 700.00$ additional when suit is appealed by the defendant to a higher court"); and Act of April 21, 1899, § 3, 1899 Ill. Laws 237, 239 (requiring casualty companies organized under Illinois law to "do business" with a minimum capital stock of $\$ 100,000$ "fully paid in cash," with an additional $\$ 50,000$ for every additional "kind of insurance" it was authorized to sell, but setting the minimum for companies insuring liability for accidental injuries at $\$ 200,000$ ).

144. Batterson to Geo. F. Seward, Esq., Prest., June 26, 1894, PL2, p. 457.

145. The Travelers Insurance Co., by J. Batterson, Objections to the Bill (H.B. No. 279), undated, PL2, p. 384-86; Batterson to Geo. F. Seward, Esq., President, dated May 7, 1894, PL2, p. 413; and Batterson to P.W. Ditto, Esq., Neil House, Columbus, Ohio, April 10, 1894, PL2, p. 389.

146. Batterson to Geo. F. Seward, Prest., March 12, 1894, PL2, p. 376.

147. Batterson to Geo. F. Seward, Prest., March 26, 1894, PL2, p. 380.

148. Petition, Fidelity \& Casualty Co. v. Hahn, Court of Common Pleas, Franklin County, Ohio, filed March 12, 1895, in Record, Supreme Court of Ohio, Fidelity \& Casualty Co. v. Hahn.

149. Batterson to Seward, June 19, 1894, PL2, p. 449; Batterson to W.C. Maybury, Esq., Managing Director, etc. [Standard Life \& Accident Co.], Detroit, Mich., December 28, 1894, PL2, p. 660. 
unconditional licenses, the denial of which would set up the lawsuit challenging the 1894 statute. ${ }^{150}$

The liability insurers' lawyers, however, had limited options. Although the 1894 statute treated out-of-state insurers worse than Ohio insurers, a federal constitutional challenge would be unlikely to succeed. It was settled that corporations did not count as "Citizens" under Article IV's Privileges and Immunities Clause. ${ }^{151}$ The United States Supreme Court had confirmed only a few months earlier that the insurance business still fell outside of Congress' Article I power to regulate "Commerce" among the several states. ${ }^{152}$ Nor would the insurers fare better by arguing that the Ohio statute violated the Fourteenth Amendment promise that no state shall "deny to any person within its jurisdiction the equal protection of the laws." In 1886, the Supreme Court had read that provision not to constrain New York from denying admission to an out-of-state insurance corporation that refused to pay, as a condition of admission, a license fee that New York imposed only on out-of-state corporations. The Court reasoned that, in those circumstances, the corporation was not "within [the state's] jurisdiction," but on the outside looking in, and therefore not eligible for whatever equal protection the Fourteenth Amendment promised. ${ }^{153}$

Instead, the insurers' lawyers primarily argued that the Ohio legislature had violated legislative process provisions of the Ohio State Constitution that governed what to put in bill titles and how to amend statutes. ${ }^{154}$ The insurers lost. ${ }^{155}$ In response, both Travelers and Standard Life and Accident paid the $\$ 50,000$ deposit, whereas both Union Casualty \&

150. Weekly Underwriter, March 9, 1895, 173; and Weekly Underwriter, May 25, 1895, 377.

151. U.S. Const. art. IV, § 2; Paul, 75 U.S. at 178-82.

152. U.S. Const. art. I, § 8; Hooper v. California, 155 U.S. 648 (1895) (decided January 7 , 1895).

153. U.S. Const. amend. XIV, $\S 1$; Fire Association of Philadelphia v. People of the State of New York, 119 U.S. 110, 119 (1886). This view is "now discarded." Western \& Southern Life Insurance Co. v. State Board of Equalization, 451 U.S. 648, 660 n. 12 (1981) (citations omitted).

154. Brief of Plaintiff in Error in Supreme Court of Ohio, Fidelity \& Casualty Co. v. Hahn (filed May 2, 1895); Petition, Fidelity \& Casualty Co. v. Hahn, Court of Common Pleas, Franklin County, Ohio, filed March 12, 1895, in Record, Supreme Court of Ohio, Fidelity \& Casualty Co. v. Hahn; Ohio Const. of 1851, art. II, § 16 ("No bill shall contain more than one subject, which shall be clearly expressed in its title; and no law shall be revived, or amended, unless the new act contain the entire act revived, or the section or the sections amended; and the section, or sections, so amended, shall be repealed.").

155. Opinion of Franklin County Circuit Court, March 30, 1895 (dismissing petition), reprinted in Appendix, Brief of Defendant in Error at 28-29; Fidelity \& Casualty Co. v. Hahn, 44 N.E. 1135 (Ohio 1895) (affirming judgment without opinion). 
Surety and Fidelity \& Casualty, stopped selling liability insurance in Ohio. In 1899 , four years after it left, the Fidelity and Casualty returned, this time agreeing to pay the $\$ 50,000$ deposit to do business in the state. ${ }^{156}$

In May 1901, the same month that the new Conference Liability Manual was issued, the Michigan legislature became the first state legislature to go beyond nominal-dollar deposit requirements and specify how liability insurers would set their liability loss reserves - that is, at a minimum of forty percent of net premiums received and, at the insurance commissioner's discretion, even more if the company's liability loss ratio consistently exceeded forty percent. ${ }^{157}$ Proponents of this legislation included the Michigan Insurance Commissioner H.H. Stevens, who less than a year earlier had traveled east to examine the liability insurance business of some of the major insurance companies, and apparently found their liability loss reserves to be inadequate. ${ }^{158}$

This time, in response to the Michigan law, the liability insurers did not go to court, as they had in Ohio years earlier. They instead lobbied for an alternative method of liability loss reserve regulation that mirrored Liability Conference practice. In 1902, Fidelity and Casualty President George Seward argued in a letter to the National Convention of Insurance Commissioners that state insurance regulators should apply the purepremium method (Frank Law's method, although Seward did not credit Law) of calculating liability premiums to the calculation of liability loss reserves. By multiplying the pure premium losses for the country as a whole by the counter-differentials for each state, one could produce "a 'standard table of experience' to be used in determining loss reserves."159 In contrast, Seward complained, Michigan's forty-percent basis for setting liability loss reserve minimums was arbitrary and its method required assuming "that all companies get equal premiums for equal hazards." This assumption, he argued, was both false and would result in smaller liability reserves for rate-cutting companies - the perverse result of

156. Weekly Underwriter, May 25, 1895, 380; and The Standard, August 26, 1899, 197.

157. Act of May 29, 1901, No. 190, § 3, 1901 Mich. Pub. Acts 268, 269-70; Proceedings of the Thirty-Third Annual Convention of Insurance Commissioners of the United States (Springfield: H.W. Rokker Co., 1903), 66, 70. In 1905, the Michigan legislature raised the minimum to fifty percent of premiums received and earned. See Act of May 25, 1905, No. 137, 1905 Mich. Pub. Acts 186, 187.

158. Frank E. Law, A Review of Liability and Workmen's Compensation Loss Reserve Legislation (New York: Fidelity \& Casualty Co., 1913), 3. The Michigan insurance commissioner's examination of Travelers had occasioned the exchange in which George Seward had referred to Travelers' President Batterson as a bull in a china shop. See text accompanying nn. 121-123.

159. Proceedings of the Thirty-Third Annual Convention of Insurance Commissioners of the United States (Springfield: H.W. Rokker Co., 1903), 67-68 (quoting Seward letter). 
requiring lower minimum reserves for liability companies with higher insolvency risk. ${ }^{160}$ Michigan's Insurance Commissioner Nelson Hadley offered a lengthy defense of the Michigan law. ${ }^{161}$ The National Convention of Insurance Commissioners ultimately refused to endorse either approach. ${ }^{162}$

Legislative efforts continued. A year later, in 1903, New York and Connecticut enacted statutes that used alternative methods for setting liability loss reserve minimums. ${ }^{163}$ On one account, the New York method enacted in 1903, and amended in 1904, had been proposed by the Travelers Insurance Company. ${ }^{164}$ Then, in 1905, five state legislatures enacted roughly the same liability loss reserve law: California, New York, Massachusetts, Illinois, and Connecticut. ${ }^{165}$ By forcing all liability insurers to set liability reserves according to the same criteria, insurance industry supporters argued, these new laws would deter rate-cutting and make those insurers maintain adequate reserves. ${ }^{166}$ The insurance trade press credited Fidelity and Casualty's George Seward with drafting such legislation in New York, ${ }^{167}$ and liability insurers with influencing its passage there as well as in California, Illinois, and Massachusetts. ${ }^{168}$ A few months later, when in September 1905 the Conference reported that it would persist, some reports in the insurance trade press asserted,

160. Ibid., 68 (quoting Seward letter).

161. Ibid., 70-72.

162. Proceedings of the Thirty-Fifth Annual Convention of Insurance Commissioners of the United States (Springfield: H.W. Rokker Co., 1905), 70.

163. Act of May 12, 1903, ch. 566, 1903 N.Y. Laws 1241, 1242-43; and Act of June 11, 1903, ch. 168, § 2, 1903 Conn. Pub. Acts 129, 130. New York amended its law in 1904. Act of April 28, 1904, ch. 468, 1904 N.Y. Laws 1173, 1174-75. See Proceedings of the Thirty-Fifth Annual Convention of Insurance Commissioners of the United States (Springfield: H.W. Rokker Co., 1905), 71.

164. Law, Review, 4.

165. Act of March 20, 1905, § 2, ch. 327, 1905 Calif. Laws 379-382; Act of March 30, 1905, ch. 113, 1905 N.Y. Laws 162; Act of April 13, 1905, ch. 287, 1905 Mass. Acts 206; Act of May 16, 1905, 1905 Ill. Laws 288; and Act of July 19, 1905, ch. 272, 1905 Conn. Pub. Acts 475. Texas enacted a similar law in 1909. Act of March 22, 1909, ch. 108, § 54, 1909 Tex. Gen. Laws 192, 208-210.

166. Letter from Sidney N. Moon to the editor of the Spectator, May 3, 1905, in "Underwriting in Liability Insurance," The Spectator, May 18, 1905, 257; and "New Liability Bill in New York Legislature," The Standard, February 4, 1905, 108.

167. "New Liability Bill in New York Legislature," The Standard, February 4 1905, 108; and "Liability Business-President Seward Advocates Law Regarding Loss Reserves," Insurance Press, February 1, 1905, 1.

168. Weekly Underwriter, June 3, 1905, 529; see also "Liability Reserves," Monthly Bulletin of the Fidelity \& Casualty Company 10 (May 1905): 68 ("The bill drawn and promoted by this company has become law in California, New York, and Massachusetts. It is likely to become law in Illinois."). 
perhaps mirroring the Conference public position, that Conference members had so decided in part because they believed that the new liability reserve statutes had or would reduce rate cutting by non-Conference rivals. ${ }^{169}$

Less than a year later, however, the Conference declared that it had abandoned its price-fixing effort. The timing here is hardly dispositive, but it is consistent with a causal story in which, assuming continued rate cutting by non-Conference rivals, the presence of liability loss reserve statutes led Conference company managers to value Conference membership less as a solvency signal. That signal plausibly started to lose its value when Michigan enacted its legislation in 1901. Conference companies, however, had good reason not to let Michigan's insurance commissioner gain a monopoly over signaling solvency and instead to criticize Michigan's approach as inferior, as Seward did in 1902. Under the Michigan law, the insurance commissioner had the discretion to raise the minimum reserve for any particular insurer, a feature that liability insurance underwriters largely opposed. ${ }^{170}$

In contrast, save for Connecticut's version, ${ }^{171}$ the 1905 statutes left no discretion to state insurance regulators to raise the company's liability loss reserve minimums above the minimum reserve prescribed by the statute. The 1905 Massachusetts law was typical. It required insurance companies with at least a decade's worth of experience in selling liability insurance to file an annual statement with the state's insurance commissioner. This statement had to contain: (1) the number of persons reported injured under all its forms of liability policies, regardless of whether such injuries resulted in loss to the insurer; (2) the amount paid "on account or in consequence of all injuries so reported," including payments on lawsuits arising from such injuries, up to August 31 of the reporting year; (3) the number of suits or actions under liability policies that arose out of the reported injuries that had been settled by "payment or compromise"; and (4) the amount paid for those settled suits on or before August 31 of the reporting year. From these data, the Insurance Department calculated the average cost per injury notice and per suit. It then multiplied each of those averages by the number of open accident and lawsuit files for every liability insurer doing business in the state. ${ }^{172}$ The result was a

169. "Decide to Continue the Liability Conference," The Standard, September 16, 1905, 259; and Weekly Underwriter, September 16, 1905, 188.

170. Proceedings of the Thirty-Fifth Annual Convention, 71-72 (reporting that majority of liability underwriters consulted by the National Convention of Insurance Commissioners' Committee on Reserves Other than Life opposed such discretion).

171. 1905 Conn. Pub. Acts at 476-77, § 3

172. 1905 Mass. Acts 206, §1. 
minimum liability loss reserve for each liability insurer derived from the loss experience of the older liability insurance companies.

To be sure, commentators criticized the 1905 statutes, ${ }^{173}$ and in 1911, state legislatures adopted another way to set liability loss reserve minimums in Washington, Massachusetts, Minnesota, Connecticut, New York, Pennsylvania, Ohio and Georgia. ${ }^{174}$ Yet, the 1911 statutes underscore how much liability insurers valued solvency regulation without regulator discretion. The National Convention of Insurance Commissioners had endorsed what became the 1911 statutes after consulting with a committee of representatives of the major liability insurance companies. ${ }^{175}$ That committee would only unanimously support a law that did not authorize the state insurance regulator to order additional liability loss reserves above the prescribed minimum. ${ }^{176}$

By then, the major liability insurers were cooperating in another way as well. In December 1910, some months after New York enacted its first workmen's compensation statute, nineteen liability insurers formed the Workmen's Compensation Service and Information Bureau-an effort to price worker compensation policies that, some months later, merged with the Liability Conference's Bureau of Liability Statistics, and later promulgated policies and rates for the growing market for automobile liability

173. Proceedings of the National Convention of Insurance Commissioners of the United States (Springfield: H.W. Rokker Co., 1908), 140 (minimum reserves not "anywhere near large enough"); S.H. Wolfe, "Reserve for Unpaid Liability Losses," Weekly Underwriter, February 15, 1908, 127-28 (similar); "The Future of Liability Insurance," The Spectator, October 11, 1906, 180 (encourages accident underreporting); and Law, Review, 9-12 (average costs of notices of injury and lawsuits vary considerably by liability insurer).

174. See Act of March 10, 1911, ch. 49, § 95, 1911 Wash. Laws 161, 236; Act of April 20, 1911, ch. 315, 1911 Mass. Acts 268; Act of April 20, 1911, ch. 315, 1911 Minn. Gen. Laws 439, 440-43; Act of April 27, 1911, ch. 44, 1911 Conn. Pub. Acts 1296; Act of May 24, 1911, ch. 183, 1911 N.Y. Laws 285, 287-91; Act of June 1, 1911, 1911 Pa. Laws 604; Act of June 12, 1911, 1911 Ohio Laws 477; Act of Aug. 22, 1911, No. 266, 1911 Ga. Laws 174; Edwin W. DeLeon, "Casualty, Surety, and Miscellaneous Insurance in the United States," in The Insurance Year Book. 1912-1913 [Life, Casualty and Miscellaneous.] (New York: Spectator Co., 1912), A-88-A-89. For criticism of this method, see I.M. Rubinow, "Liability Loss Reserves," Proceedings of the Casualty Actuarial and Statistical Society of America 1 (1915): 279-94.

175. Weekly Underwriter, June 4, 1910, 444 (naming committee members).

176. William T. Emmett, "Adequate Reserves Against Employers' Liability and Workmen's Compensation Risks," in Proceedings of the National Convention of Insurance Commissioners of the United States (Columbia: R.L. Bryan Co., 1912), 22930; Benedict D. Flynn, "Statistics and Reserves," in The Business of Insurance, 323-24; and Proceedings of the National Convention of Insurance Commissioners of the United States, vol. 2 (Helena: State Publishing Co., 1910), 170-72. 
insurance. ${ }^{177}$ In some states, this effort operated with express regulatory sanction. For example, the New York legislature had enacted in 1911 the first statute to expressly sanction fire insurance rating bureaus and rely on their rate manuals to police insurers for any "unfair" price discrimination. ${ }^{178}$ In 1912, the New York legislature amended that law to authorize rate-making associations for other kinds of insurance, including liability and workmen's compensation insurance, as well as automobile liability insurance. ${ }^{179}$

\section{Conclusion}

A decade after liability insurance for personal injury accidents came to America, the leading liability insurance companies agreed to fix premium rates and pool liability loss information. This article discussed four possible reasons why the cartel abandoned their price-fixing effort in 1906: price competition by non-Conference rivals; defection by Conference companies; fear of state competition laws; and state regulation of liability loss reserves.

This article concluded that price competition by non-Conference rivals played an important role in the Conference's fall. In contrast, state competition law appears not to have made much of a difference. This article found insufficient evidence to assess the importance of Conference member defection. Finally, on the available evidence, it is at least plausible that state solvency regulation of liability insurance loss reserves reduced the

177. Fifty-Ninth Annual Report of the Superintendent of Insurance of the State of New York: Part V (Albany: J.B. Lyon Co., 1918), 831-82 (report of examination of National Workmen's Compensation Bureau, August 15, 1917); Report on Workmen's Compensation Insurance of the Commission to Investigate Practices and Rates in Insurance (Boston: Wright \& Potter, 1915), 14-22; Fifty-Fifth Annual Report of the Superintendent of Insurance of the State of New York: Part V (Albany: J.B. Lyon \& Co., 1914), 1142-74 (report on Workmen's Compensation Service, July 30, 1913); and DeLeon, "Casualty, Surety, and Miscellaneous Insurance in the United States," A-89, A-92.

178. Act of June 28, 1911, ch. 460, 1911 N.Y. Laws 1062. On the spread of fire insurance regulation after Kansas (1909), see Marc Schneiberg and Tim Bartley, "Regulating American Industries: Markets, Politics and the Institutional Determinants of Fire Insurance Regulation," American Journal of Sociology 107 (2001): 111-15, 138.

179. Act of April 5, 1912, ch. 175, § 1, 1912 N.Y. Laws 317. State sanction of cooperative rate-setting spread faster for fire insurance. Francis R. Stoddard, Jr., "The State Supervision and Regulation of Insurance Rates," in Proceedings of the Fifty-Third Annual Session of the National Convention of Insurance Commissioners (Richmond: J. W. Fergusson \& Sons, 1922), 112-13 (tally of states permitting rating bureaus for, among other things, fire insurance, workmen's compensation, and liability insurance). 
value of Conference membership as a signal of company solvency, and thereby contributed to the Conference's fall.

In reaching these conclusions, this article is limited in part by its main sources of evidence: insurance trade journals, state insurance regulator reports, company bulletins, annual firm-level business data as well as the surviving correspondence of two company presidents. In contrast to such evidence, primary materials generated by insurance sales agents may contain much evidence about agent attitudes and sales strategies, which might help assess, for example, the solvency-signal explanation or how often companies defected from the Conference agreement.

This article makes two main contributions. First, it confirms the expectations of both cartel theory and past research on insurance cartels by showing how insurers engaged in unstable price-fixing efforts and shared information to better estimate future claims costs. Second, and perhaps more important, this article offers a deviant case for accounts of the legal influences on American industrial organization. Even if antitrust law and corporate law partially explain the great merger wave, most industries at the time did not experience significant consolidation activity, and these industries varied substantially in organizational form and inter-firm cooperation, among other things. The rise and fall of the first liability insurance cartel raises the possibility that future studies of other industries will reveal a far greater range of possible legal influences on, and thereby help better explain, American industrial organization at the turn of the twentieth century. 